\title{
La interpretació de la ironia literària en estudiants de secundària
}

\author{
Laura Traver i Planella* \\ Mariona Casas Deseuras **
}

\section{Resum}

El present treball proposa un estudi qualitatiu a través d'una activitat de comprensió lectora i d'un qüestionari d'hàbits lectors a estudiants de diferents cursos -1r d'ESO, 3r d'ESO i 1r de batxilleratdel mateix centre educatiu i de tres entrevistes a docents per a observar com perceben la ironia d'un text literari els estudiants. Els resultats demostren que la capacitat d'interpretació de la ironia resulta un punt feble en les competències, relacionades amb les dimensions literàries i de comprensió lectora, dels cursos de $1 \mathrm{r}$ i $3 \mathrm{r}$ d'ESO, i mostren, en canvi, un cert domini d'aquestes competències a $1 \mathrm{r}$ de batxillerat. Com a conseqüència, el treball proposa algunes actuacions i orientacions didàctiques dirigides als docents per a treballar la ironia a l'aula.

\section{Paraules clau}

Ironia, interpretació, reflexió, secundària, aprenentatge, literatura, comprensió lectora.

Recepció original: 24 de novembre de 2020

Acceptació: 18 de febrer de 2021

Publicació: 1 de juliol de 2021

\section{Introducció}

En el context educatiu és ben sabut que l'observació activa i l'anàlisi dels processos d'aprenentatge dels estudiants és un element clau a l'hora de poder determinar l'eficàcia i la viabilitat de la tasca docent. Per tant, fixar-nos en els nostres alumnes ens pot donar moltes pistes d'allò que els professors fem reeixidament i dels àmbits on cal intervenir per a aconseguir una millora. Precisament, fou en una de les sessions de l'assignatura de Formació Literària, Lectura i Educació del Màster Universitari de Formació del Professorat d'Educació Secundària Obligatòria que es posà sobre la taula una de les mancances de l'alumnat a l'hora de treballar la literatura a l'aula, fet que, de seguida, sorgí un interès especial atesa l'estreta relació que mantenia la problemàtica assenyalada amb la branca literària en la qual havia recercat prèviament: com s'havia traslladat la característica ironia dels relats breus de Quim Monzó a El perquè de tot plegat al seu homònim cinematogràfic (Traver, 2019). Així doncs, la inquietud per a l'elaboració d'aquest treball sorgeix de la perceptible preocupació d'alguns docents del fet que als adolescents d'avui en dia els costa percebre i interpretar les expressions iròniques i satíriques que apareixen als relats literaris.

$\left(^{*}\right)$ Graduada en Llengua i Literatura Catalanes (2019) per la Universitat Oberta de Catalunya i Màster de Formació del Professorat en l'especialitat de Llengua i Literatura Catalana i Castellana (2020) per la Universitat de Vic-Universitat Central de Catalunya. Professora de llengua i literatura catalanes a secundària. Aquest treball, dirigit per la professora Mariona Casas, va guanyar la vuitena edició, corresponent a l'any 2020, del Premi Sebastià Álvarez al millor TFM de la Facultat d'Educació, Traducció i Ciències Humanes de la Universitat de Vic-Universitat Central de Catalunya. Adreça electrònica: laura.traver@uvic.cat

$\left(^{* *}\right)$ Doctora en Didàctica de la Llengua i la Literatura (2012) per la Universitat Autònoma de Barcelona. Professora del Departament de Filologia i de Didàctica de la Llengua i de la Literatura a la Universitat de Vic-Universitat Central de Catalunya (UVic-UCC). Membre del Grup de Recerca en Educació, Llenguatge i Literatura (GRELL). Adreça electrònica: mariona.casas@uvic.cat. https://orcid.org/0000-0002-3992-5540 
De fet, així mateix ho han expressat alguns docents a la premsa. Per exemple, Pàmies $(2018$, p. 1) explica que aquesta problemàtica està precisament sobre la taula en algunes de les converses quotidianes amb professors amb força anys d'experiència: «[els professors] estan d'acord que els alumnes cada vegada tenen menys comprensió lectora i que estan perdent la capacitat de detectar la ironia, les referències i les intencions del que llegeixen». Malgrat que, confessa, es tracta d'una generalització, l'autor atribueix aquesta mancança a «la immediatesa, que [...] obliga els alumnes a viure en una competició implícita que estableix que qui reacciona més ràpid és més popular o tecnològicament avançat i que afecta la construcció del criteri». En un moment en el qual la gran part de la lectura de l'alumnat és a través de les pantalles, Pàmies assegura que la ironia i les referències són les primeres víctimes, atès que requereixen una predisposició de degustació que la tecnologia difícilment estimula (Pàmies, 2018, p. 1). De fet, Royo ja fa èmfasi d'aquesta mena de cultura de la immediatesa en la qual vivim: «Si nosotros vamos rápido, nuestros hijos, nuestros alumnos, más, pese a que su ritmo es en realidad mucho mas pausado. Pero no les permitimos el sosiego. Los sobreestimulamos y obstaculizamos su capacidad de asombro» (Royo, 2017, p. 96-97).

Larregola, per la seva banda, s'aventura a afirmar que «la ironia se'ns mor» (2019, p. 1). El professor assegura que la pròpia experiència li fa lamentar l'absència de la ironia, el sarcasme i els dobles sentits entre els alumnes de secundària i batxillerat: «Els alumnes entenen a la perfecció allò que està escrit, però fracassen en desxifrar allò que no està dit explícitament» (Larregola, 2019, p. 1). A diferència de Pàmies, Larregola atribueix aquesta problemàtica a la pèrdua de tabús socials que fan que avui dia «perdem els camuflatges» lingüístics que poden convidar a l'ús de la ironia i al fet que es treballa amb els alumnes una comprensió lectora excessivament planera, endolcida i adequada a la seva edat: «sembla com si avui dia els textos per a infants i joves donessin per descomptada la seva inutilitat lectora, la seva total dependència de la literalitat» (Larregola, 2019, p. 1).

Per tant, el primer objectiu del treball és analitzar com es percep i s'interpreta la ironia literària durant l'etapa adolescent amb la finalitat d'esbrinar si representa un punt feble en les competències relacionades amb les dimensions literàries i de comprensió lectora dels estudiants. Per fer-ho, s'ha dut a terme un estudi consistent en una activitat de comprensió lectora en alguns cursos d'ESO i Batxillerat d'un centre públic de secundària de la comarca de la Garrotxa amb aproximadament uns 900 alumnes, repartits entre les etapes d'ESO, Batxillerat i Cicles Formatius. En conseqüència, i per tal de contextualitzar els resultats, els objectius secundaris són conèixer els hàbits lectors dels estudiants per poderlos relacionar amb la seva capacitat d'interpretació de la ironia, descobrir el punt de vista del professorat pel que fa a la capacitat lectora i interpretativa dels alumnes i, per últim, investigar com es presenta la percepció i interpretació de la ironia en tres cursos diferents -1r d'ESO, 3r d'ESO i 1r de Batxillerat- per tal de comprovar si es produeix una evolució positiva de les capacitats descrites. A partir dels resultats obtinguts, aquest estudi pretén, com a segon objectiu, determinar algunes orientacions i actuacions acadèmiques útils i a tenir en compte per al docent a l'hora de treballar la ironia literària a l'aula.

Així doncs, el contingut d'aquest treball hauria de respondre a les següents preguntes: com és percebuda i interpretada la ironia literària en l'etapa de l'adolescència dels estudiants del centre en qüestió? De quina manera es relacionen o no els seus hàbits lectors amb la seva capacitat interpretativa de la ironia? Com perceben els professors del centre la capacitat lectora i interpretativa dels estudiants? Com es presenta la capacitat interpretativa i perceptiva de la ironia en els estudiants de $1 \mathrm{r}$ d'ESO? I en els de $3 \mathrm{r}$ d'ESO? 
I en els de 1r de Batxillerat? Hi ha cap mena d'evolució positiva de les capacitats al llarg dels cursos? Per tant, quins factors cal tenir en compte i quines estratègies pot emprar el docent a l'hora de treballar la ironia a l'aula?

\section{Fonamentació teòrica}

Abans d'entrar en la discussió sobre la hipòtesi que representa la base d'aquest estudi als alumnes els costa percebre i interpretar la ironia textual-, fora bo plantejar-se què entenem per ironia i quines són les diverses concepcions que en tenen alguns estudiosos. A continuació, s'analitzarà el paper que avui en dia té l'ensenyament-aprenentatge de la ironia a les aules.

\section{Què entenem per ironia?}

Barreras exposa la definició que més s'acosta a la percepció general: «se entiende que la ironía ocurre en el contraste entre aquello que se hace o dice y el mensaje que realmente se quiere transmitir» (2001, p. 245). És a dir, un enunciat irònic és aquell que expressa el contrari d'allò que precisament es vol comunicar. De fet, sovint la ironia és percebuda com una figura retòrica i, si bé aquesta afirmació és certa, les possibilitats que ens ofereix aquest recurs lingüístic van molt més enllà:

Si pensamos [...] que muchas [...] figuras son convencionalmente usadas, llegamos a la conclusión de que la metáfora, la metonimia y la ironía [...] no son sólo un elemento del lenguaje, ni simples artificios literarios que se utilizan en la poesía o la literatura en general, sino que son fenómenos que residen en nuestro sistema conceptual y se utilizan con una clara intención comunicativa aunque el hablante no siempre sea consciente de ello. (Villarubia, 2010, p. 29)

Ara bé, la ironia, entesa com un recurs comunicatiu, no és ni universal ni unidireccional i, consegüentment, per tal que sigui efectiva fa falta un context lingüístic adequat, la participació implícita de l'emissor i del receptor i la capacitat d'interceptar-la i interpretarla:

La ironía pertenece al ámbito de la pragmática en cuanto que se percibe en unas situaciones concretas, y que depende de la intención de la persona que emite el enunciado irónico, pero también en gran medida de la capacidad de descodificar el mensaje por parte del oyente o lector. (Villarubia, 2010, p. 29)

Per tant, el context en el qual s'utilitza la ironia és imprescindible per a la seva òptima interpretació. Probablement, per tant, l'emissor serà més propens a percebre i comprendre la ironia en un text si comparteix el mateix context sociocultural que l'emissor. Contràriament, el text irònic «se puede entender literalmente de forma inocente por el lector que no percibe esa ironía» (Barreras, 2001, p. 248). Per tant, un relat que presenti ironia sempre tindrà un significat doble: el literal i innocent i, per altra banda, l'irònic, el qual serà apreciat pel bon lector.

Pel que fa als trets característics d'un text per tal que pugui ser identificat com a irònic, Barreras assegura que «las evidencias que se pueden encontrar en el texto, que transparentan su carácter irónico, no pueden ser otras, contenido aparte, que las estructuras narrativas y lingüísticas» (Barreras, 2001, p. 248). Per tant, més que no pas en el contingut, hom s'ha de fixar en la forma d'escriptura del text en qüestió. En concret, Ballart especifica sis condicions imprescindibles que hauria de satisfer tota ironia per ser considerada com a tal:

1) un domini o camp d'observació; 2) un contrast de valors argumentatius; 3 ) un determinat grau de dissimulació; 4) una estructura comunicativa específica; 5) una coloració afectiva; i 6) una significació estètica. 
Vull dir amb tot això que només quan hi concorrin aquests sis factors podrem dir amb propietat que el text s'adapta a una figuració de caràcter irònic. (Ballart, 1992, p. 8)

Cal fer notar que, en efecte, cap de les sis condicions es refereix directament al contingut i, per tant, una bona comprensió literal del text no és en absolut suficient per a dominar les arts de la ironia. Caro, Camargo i Uribe (2018), per la seva banda i a tall de validació i concreció de les idees exposades per Ballart, corroboren la diversitat de variables i de condicions que s'han d'ajuntar per donar lloc a una òptima comprensió de la ironia. Per tant, la ironia no només és complexa d'interpretar sinó que, a més, demanda al receptor un bagatge cultural ampli:

Conocimiento enciclopédico general, conocimiento enciclopédico específico sobre el interlocutor, conocimiento de sucesos o acciones que han ocurrido hacer relativamente poco tiempo, enunciados previos, comunicación no verbal vocal, elecciones léxicas o gramaticales, información proveniente del entorno físico que rodea a los interlocutores. (Caro, Camargo i Uribe, 2018, p. 106)

\section{L'ensenyament-aprenentatge de la ironia a l'aula}

Un cop delimitada la complexitat que implica el terme, vegem de quina manera és tractada la ironia en el currículum educatiu actual. El primer que cal remarcar és que el terme ironia no apareix de manera explicitada com a contingut específic d'aprenentatge ni en la Llei 12/2009 d'Educació ni en el Decret 187/2015. Ara bé, l'ús i el coneixement dels procediments relacionats amb la ironia es podrien relacionar amb una de les finalitats del currículum, plasmades en I'article 52 de la Llei 12/2009: «Aconseguir que els alumnes adquireixin unes bones habilitats comunicatives, una expressió i comprensió orals, una expressió escrita i una comprensió lectora correctes i el domini dels nous llenguatges» (2009, p. 28). Pel que fa al Decret 187/2015, i malgrat que tampoc s'expliciti la ironia, podem trobar diverses competències i continguts relacionats amb l'àmbit comunicatiu que poden implicar-la. En aquest sentit, en el marc de la competència en comprensió escrita, s'accentua la importància de saber emprar tres processos fonamentals en la comprensió i interpretació dels textos: la lectura literal, la lectura interpretativa o inferencial i, per últim, la lectura reflexiva o valorativa, «que implica posar en funcionament els coneixements externs del text i previs del lector, requereix saber desenvolupar una comprensió global del text, integrar i deduir-ne la informació no explícita» $(2015$, p. 23), processos que es comparteixen amb la comprensió de la ironia. El mateix succeeix amb les competències en comunicació oral, on apareix la importància de «valorar de manera crítica i raonada els continguts i els propòsits dels textos orals» $(2015$, p. 29) i, com a continguts clau, els processos de comprensió oral, la pragmàtica, els elements de la comunicació i els elements d'estil. Pel que fa a la dimensió literària, s'apunta com un dels continguts clau la lectura i la comprensió de textos pel que fa a l'estructura, els aspectes formals, els recursos estilístics i retòrics $(2015$, p. 35).

Amb relació als continguts clau pel que fa als diferents nivells i que poden tenir a veure amb els processos de comprensió de la ironia, a tots quatre cursos de secundària apareixen, en la dimensió de comprensió lectora, les estratègies de comprensió lectora: la intenció comunicativa i l'actitud del parlant, les inferències i el contrast amb els coneixements propis (2015, p. 42). En la dimensió literària, dins les estratègies i tècniques per analitzar i interpretar el text literari abans, durant i després de la lectura, hi apareixen els recursos estilístics i retòrics, dels quals se n'especifiquen l'anàfora, la metàfora, la metonímia, el símil, l'antítesi, I'hipèrbaton, la hipèrbole i l'enumeració (2015, p. 42). A segon curs s'hi afegeix el paral-lelisme (2015, p. 42), a tercer curs; l'al-literació, el pleonasme, la paradoxa, l'asíndeton i el polisíndeton $(2015$, p. 54$)$ i, per últim, a quart curs s'hi sumen el 
quiasme, la sinestèsia i l'al-legoria (2015, p. 60). Per altra banda, no és fins a tercer curs quan, en el bloc transversal de coneixement de la llengua i en l'apartat de pragmàtica, hi apareixen per primer cop els elements de comunicació i les funcions del llenguatge (2015, p. 55), continguts que queden també plasmats a quart curs. De fet, és precisament en el bloc de pragmàtica de la llengua, segons la visió de Villarrubia, on millor s'encabiria l'ús de la ironia, atès que, com s'ha comprovat, es tracta d'un recurs comunicatiu que resideix en el nostre sistema conceptual de parla i que va molt més enllà d'una simple figura retòrica (2010, p. 29).

Mentre que el Decret 187/2015, tal com hem comprovat, no cita en cap moment la ironia, sí que hi té cabuda en el document de Competències Bàsiques de l'Àmbit Lingüístic. Paradoxalment, apareix en les competències 7 i 9, relacionades amb la llengua oral. En concret, el terme és citat en les orientacions metodològiques per al treball a l'aula de la comprensió oral: «el docent pot proposar [treballar la llengua oral] a partir de l'observació dels sentits figurats, sobretot l'ús de la ironia» $(2015$, p. 35). A més, també apareix com un paràmetre en les orientacions d'avaluació de les competències en llengua oral 7 i 9 i, concretament, en l'indicador del nivell 3 -és a dir, en la indicació que atorgaria a l'estudiant la qualificació més alta- de la següent manera «capta la ironia, els dobles sentits» (2015, p. 35) $\mathbf{i}$ «expressa sentiments $i$ sentit de l'humor amb ironia sense ofendre» $(2015$, p. 41), respectivament. La ironia també fa acte de presència en la competència 11, relacionada amb la dimensió literària i, en concret, amb «expressar, oralment i per escrit, opinions raonades d'obres literàries, tot identificant gèneres, i interpretant i valorant els recursos literaris dels textos» (2015, p. 49). Tal com passa en el cas anterior, apareix en les orientacions d'avaluació i en l'indicador de nivell 3 de la rúbrica a partir del següent paràmetre: «Interpreta i valora críticament l'ús dels recursos estilístics: metàfora, ironia, símbol...» $(2015$, p. 51).

S'ha comprovat, per tant, que la ironia apareix molt tímidament en els documents prescriptius educatius i que ho fa d'una manera ambigua i vaga, atès que no representa un contingut específic d'una dimensió en concret i s'hi troben traces en diferents grups competencials: comprensió escrita i oral, producció escrita i oral, dimensió literària, bloc transversal de coneixement lingüístic, etc. Aquest fet, per una banda, no fa més que corroborar que la ironia forma part de la competència comunicativa en general i que no és tan sols un recurs retòric textual i, per l'altra banda, explica el fet que no hi ha unes directrius o objectius clars pel que fa al treball d'aquest recurs lingüístic a l'aula que poden fer, com a conseqüència, que es toqui d'una manera molt superficial o que, directament, no se li dediqui un temps específic.

De fet, la majoria d'estudiosos de la ironia estan d'acord amb la importància d'encabir-la com a forma comunicativa en el dia a dia de l'activitat educativa:

El acto de habla indirecto y con valor irónico es recurrente como forma comunicativa y también ha de ser aprendido por el alumno para poder entender realmente qué ocurre en su entorno, al igual que el uso y violación de las máximas conversacionales. (Roca, 2009, p. 754)

Malgrat això, però, cal tenir en compte que, per a l'alumnat, ni la comprensió lectora ni la percepció de la ironia són tasques senzilles i, per tant, requereixen ser ensenyades i, sobretot, practicades l'aula: «a diferencia de otros sentidos no literales, el lenguaje figurado requiere más esfuerzo inferencial» (Zamorano, 2015, p. 42). Són, per tant, nombrosos i diversos els factors que intervenen en la percepció i interpretació de la ironia. Barre- 
ras assegura que «el proceso de la comprensión de la ironía tiene que ver con el descubrimiento de la/s implicatura/s que aparece/n en el texto» (Barreras, 2001, p. 247), entenent les implicatures com els significats extra que podem deduir a partir d'aquell buit que es crea entre un sentit obert i la intuïció pragmàtica, i que poden tenir lloc en el comentari dels personatges o en el comentari de l'autor. Barreras recalca la dificultat i el temps que pot requerir el domini d'aquestes implicatures per part del receptor -en aquest cas, els nostres alumnes-:

\begin{abstract}
En el caso de la comprensión de la ironía debemos tener presente las presuposiciones dadas por conocidas por parte del enunciador y las implicaturas que hayan podido aparecer en lo ya dicho por éste, así como los conocimientos unidos a cualquier concepto de las presunciones que se vean asociadas a los conocimientos ya unidos al propio contexto. Todo esto puede significar un gran esfuerzo de procesamiento por parte del receptor, así como la necesidad del tiempo suficiente para el procesamiento de datos. (Barreras, 2001, p. 248)
\end{abstract}

Un altre dels factors que influeixen és la comprensió de la intencionalitat de l'autor. Barreras comenta que això «se evitaría si el enunciador utilizara suficientes evidencias que hicieran inferir el carácter irónico del mensaje» (Barreras, 2001, p. 247). Ara bé, cal tenir en compte que l'èxit de la comunicació depèn, en part, de l'habilitat del receptor d'inferir la intenció irònica de l'anunciador.

\begin{abstract}
Un buen número de lectores pasaron por alto la intención irónica del autor y tropezaron con la construcción del texto base, por lo que se adhirieron, más bien, a algún detalle del código de superficie y juzgaron, a priori, desde el marco situacional, amparados por sus conocimientos previos. (Caro, 2017, p. 113)
\end{abstract}

Així doncs, quan el receptor no comprèn la intencionalitat del text, pot succeir el mateix que en el cas dels lectors que formaven part de l'estudi de Caro, consistent en l'anàlisi dels comentaris dels lectors sobre textos irònics. Ara bé, la percepció i interpretació de la ironia, però, van més enllà de la capacitat lectora de l'alumne: Zamorano afirma que es requereixen, tal com hem comprovat i asseguren Caro, Camargo i Uribe, uns certs coneixements previs i un bagatge cultural i social prou ampli per poder-la interceptar:

\begin{abstract}
El papel del contexto en la comprensión de la ironía sería crucial, puesto que el esfuerzo cognitivo necesario hasta llegar a determinar el significado irónico implícito puede verse reducido significativamente si el oyente dispone de las suficientes fuentes de información contextual, de modo que la cantidad de esfuerzo cognitivo necesario dependerá del tipo de información manifiesta procedente de una o varias fuentes activadas simultáneamente. Cuando la cantidad de información manifiesta disponible sea insuficiente, los hablantes pueden incluso no darse cuenta del significado irónico intencionado del hablante. (Zamorano, 2015, p. 47)
\end{abstract}

Roca, per la seva banda, corrobora l'afirmació de Zamorano i afegeix que la comprensió de la ironia no depèn exclusivament del domini lingüístic dels aprenents:

\footnotetext{
En la ironía intervienen elementos puramente lingüísticos y pragmáticos, interrelacionados todos dentro del ámbito cultural. Si bien la ironía es un fenómeno lingüístico, su uso es cultural, así como el objeto temático ironizable y los valores que tienen. (Roca, 2009, p. 757)
}

Mal que ens pesi, difícilment podrem incidir a curt termini amb el bagatge cultural de l'alumnat per tal que comprengui millor la ironia. Ara bé, com a professors de llengua seria positiu dur a terme un acompanyament dirigit a la detecció, reflexió i interpretació dels recursos irònics com a mitjà per encarar i dominar l'activitat comunicativa quotidiana i, per tant, facilitar la finalitat socialitzadora de l'educació.

\title{
Metodologia
}

L'objectiu del treball és analitzar com es percep i s'interpreta la ironia literària durant l'etapa adolescent. La intenció, per tant, era obtenir les dades més genuïnes possibles, 
respectant així la visió de cada estudiant en relació amb la comprensió textual. És per aquest motiu, doncs, que s'ha emprat una metodologia qualitativa en tots els processos de recollida de dades per a l'elaboració d'aquest treball. En concret, la recerca parteix de tres tipus de dades diferents, totes elles qualitatives, inferencials, interpretatives i reflexives, que s'especificaran a continuació.

El gruix principal d'informació s'ha extret a partir d'una activitat de comprensió lectora i d'un qüestionari sobre hàbits lectors adreçats als estudiants. La manera més reeixida per comprovar de primera mà el grau de percepció, interpretació i comprensió de la ironia dels alumnes d'un text no era altra que, precisament, mitjançant una activitat de comprensió lectora d'un relat potencialment irònic. És per aquest motiu que se'ls demanava que llegissin un relat breu i responguessin sis preguntes relacionades amb la premissa que no hi havia respostes correctes ni incorrectes, sinó que el que es valorava era, per sobre de tot, una interpretació personal del text i de les respostes proporcionades. A partir d'aquesta activitat es pretenia, per tant, observar l'habilitat dels alumnes a I'hora de respondre diferents tipologies de preguntes que requerien els tres processos fonamentals en la comprensió i interpretació dels textos -a partir de dues preguntes de resposta literal, dues que requerien una resposta inferencial i dues que demandaven més reflexió per part de l'aprenent- amb la finalitat de comprovar quines responien amb més facilitat i, com a conseqüència, observar com era percebuda la ironia.

Posteriorment a la realització d'aquesta activitat, s'adjuntava en l'última cara de l'imprès un qüestionari amb deu preguntes de resposta breu i oberta sobre els seus hàbits lectors, sobre què creien que era la ironia i com es podia detectar i sobre les preguntes que els havien semblat més fàcils i més complicades. Aquest qüestionari calia fer-lo al final i respectar l'ordre establert de resposta per tal que les preguntes sobre hàbits lectors o sobre la ironia no els condicionessin a l'hora de realitzar la comprensió lectora. L'objectiu d'aquest qüestionari era poder col-lacionar les respostes dels alumnes dels seus hàbits lectors amb les respostes de la comprensió lectora per comprovar si, realment, l'hàbit de lectura condicionava en la interpretació de la ironia.

Totes dues activitats es van dur a terme amb les mateixes condicions -és a dir, a partir de la lectura del mateix text i la resposta de les mateixes preguntes de comprensió lectora i sobre els seus hàbits lectors- a tres grups-classe diferents: un grup de $1 \mathrm{r}$ d'ESO, un grup de $3 r$ d'ESO i un grup de $1 r$ de batxillerat, amb la finalitat d'observar la diferència entre les respostes i, per tant, comprovar si es duia a terme una evolució creixent i gradual de la qualitat de les respostes a mesura que augmentava, paral-lelament, l'edat de l'aprenent.

L'altra part de la informació del treball s'ha extret del contingut d'entrevistes, estructurades i de resposta oberta, a tres professors en les quals se'ls preguntava sobre la seva pròpia visió de la percepció de la ironia dels aprenents i sobre les causes que creien que hi influïen. L'objectiu d'aquestes entrevistes és poder contrastar la realitat plasmada a través de les comprensions lectores i els qüestionaris d'hàbits lectors amb la percepció dels professors per tal de veure si coincidien.

\section{Participants}

En total, s'ha comptat amb la participació de 51 individus de la comunitat educativa de I'institut de secundària on es realitzà l'estudi: 3 professors i 48 alumnes, 17 dels quals eren 
$1 r$ d'ESO, 15 dels participants eren de $3 r$ d'ESO i 16 dels participants eren de $1 r$ de batxillerat de la branca humanística. Val a dir que tots els alumnes, a partir dels quals s'han obtingut informació per aquest treball, han estat autoritzats pels seus pares, mares o tutors legals per a participar en la recollida de dades.

Tots tres professors són de l'especialitat de Llengua Catalana, porten una mitjana de trenta anys dedicats a la professió i duen a terme la docència al segon cicle d'ESO i a batxillerat. Algunes de les assignatures que imparteixen durant el curs 2019-2020 són Llengua Catalana i Literatura de 3r, 4t d'ESO i batxillerat, Cultura Clàssica a 3r d'ESO, Llatí a 4t d'ESO, Literatura Universal i Literatura Catalana de batxillerat, entre d'altres. Dos dels participants són els professors de l'assignatura en la qual es realitzà la recollida de dades al grup-classe.

Pel que fa a l'alumnat, els 17 participants de 1r d'ESO formaven part d'un mateix grupclasse en I'assignatura de Llengua Castellana i Literatura. Per tant, els alumnes, de 13-14 anys, van dur a terme la tasca de comprensió lectora i l'enquesta sobre hàbits lectors en castellà. És a dir, es tractava d'una traducció de la versió en català. Hi van participar tots els alumnes del grup-classe a excepció d'aquells que, durant les sessions de l'assignatura, assistien al grup de reforç.

El mateix passà amb els alumnes de 3r d'ESO: els 15 alumnes que participaren formaven part del mateix grup-classe de l'assignatura de Llengua Catalana i Literatura i no entraren en l'estudi aquells estudiants que assistien al grup de reforç durant les sessions de l'assignatura. Els alumnes, de 14-15 d'edat, van dur a terme la tasca de comprensió lectora i l'enquesta sobre hàbits lectors en català.

Per últim, tots els 16 alumnes del grup-classe de $1 r$ de batxillerat humanístic, de 1617 anys, que feien l'assignatura de Literatura Universal van participar en la recollida de dades en català. Per tant, a diferència dels grups de $1 r$ i $3 r$ d'ESO en els quals una petita part del grup -corresponent als alumnes amb més dificultats d'aprenentatge i que, per tant, assisteixen a grups de reforç de llengua castellana o catalana respectivament- no va participar en l'estudi, en el grup de $1 \mathrm{r}$ de batxillerat es van recollir dades de tot el grupclasse.

\section{Eines de recollida de dades}

Les dades recollides han format part d'una activitat per a les assignatures de Llengua Castellana i Literatura en el cas de $1 r$ d'ESO, de Llengua Catalana i Literatura en el cas de $3 r$ d'ESO i de Literatura universal en el cas de $1 r$ de Batxillerat. Per aquest motiu, era convenient que l'eina de recollida de dades per 1r d'ESO fos en llengua castellana i, en canvi, per $3 r$ d'ESO i batxillerat fos en llengua catalana. Paral-lelament, aquest exercici podia representar una activitat d'aprenentatge per a l'assignatura i, de fet, en el cas de $3 r$ d'ESO s'optà per fer-la a tot el grup-classe, independentment dels alumnes autoritzats, per tenir-la en compte en l'avaluació de l'assignatura.

L'objectiu de l'activitat era que els alumnes llegissin un text que contingués ironia i responguessin algunes preguntes que requerissin diferents processos, vinculats a la comprensió lectora i recollits al Decret 187/2015: la lectura literal, la lectura interpretativa o inferencial i, per últim, la lectura reflexiva o valorativa $(2015$, p. 23$)$, per tal d'observar com es desenvolupaven els alumnes en cadascun d'ells. 
Com que el temps per realitzar l'activitat era relativament ajustat (no més d'una sessió de 55 minuts), es va optar per emprar un relat breu, atès que oferia diverses característiques a favor de l'activitat. En primer lloc, s'optà per aquesta mena de text per la seva brevetat: «En un relato corto no hay ni argumentos secundarios, ni personajes secundarios, ni largas descripciones. Esto hace que, a diferencia del lector de novelas, al lector de relatos le sea más fácil recordar el relato» (Barreras, 2014, p. 56) i, per tant, es busca fomentar la precisió de les respostes de l'aprenent. Així, un altre benefici d'haver presentat la lectura del relat i no pas del fragment d'una novel.la és que «el interés del lector de la narración breve se centra en esa situación única del relato y no llega a identificarse con el personaje, puesto que lo más importante del relato es el incidente y no el personaje» (Barreras, 2014, p. 56). A més a més, la brevetat del relat fa que els lectors siguin especialment conscients del final (Barreras, 2014, p. 56). En conclusió, per tant, «el relato exige más la participación activa del lector». Aquest fet, doncs, fa que el receptor hagi de «construir hipótesis y deducir hechos que no se especifican en el texto. El papel del lector es acabar de completar la información que no da el narrador pero que sugiere el relato, ya que se trata de un género breve» (Barreras, 2014, p. 58). Per tant, la intenció d'emprar un relat en la comprensió lectora era facilitar i fomentar la interpretació i reflexió pròpia de l'aprenent.

Després d'haver recercat sobre la literatura irònica monzoniana, vaig optar per emprar un relat breu de Quim Monzó, autor canònic de la literatura catalana pel seu ús estès de la ironia i dels tòpics: «Monzó tracta una gran varietat de temàtiques. Ara bé, totes elles prenen sentit a través d'un element que ocupa gran part del recopilatori [El perquè de tot plegat]: la ironia» (Traver, 2019, p. 17). De fet, l'autor ha emprat la ironia com una mena de modalitat literària, «el que il.lumina el tret estilístic predominant a les paròdies de Monzó» (Lunati, 2001, p. 31-32). Així, un relat de Monzó és una opció reeixida per diverses raons: «la seva escriptura és una mena de mirall que reflecteix la realitat però d'una manera una mica deformada: Monzó desplega, més enllà de I'humor, una àcida mirada crítica a la condició humana» (Traver, 2019, p. 12), per la qual cosa les temàtiques dels seus relats podrien donar lloc a una gran diversitat d'interpretacions per part de l'alumnat: «Monzó busca provocar, generar una reacció al lector» (Traver, 2019, p. 17). Així mateix ho corrobora Lunati amb relació als finals dels seus contes:

\footnotetext{
I és gràcies a la ironia que aquestes paròdies defugen la conclusió definitiva de la història. Els finals oberts, o quasi podríem dir-ne no-finals, tan freqüents en els relats de Monzó, no sempre s'estructuren a partir del final amb efecte recomanat per Edgar Allan Poe, que anava encaminat, de fet, a trobar fórmules alternatives de tancament. La resistència d'aquestes paròdies a oferir el control d'un final conclusiu exposa el text monzonià a interpretacions diverses, no necessàriament excloents. (Lunati, 2001, p. 31-32)
}

Les possibles interpretacions dels relats dels quals Lunati parla resulten un element imprescindible per observar les diferents mirades dels alumnes envers la concepció text. La tria del conte en concret, per tant, compleix amb el característic final obert monzonià que juga amb la diversitat interpretativa: «¿Perquè les busques dels rellotges giren en el sentit de les busques dels rellotges?» de la recopilació de contes El perquè de tot plegat. Es tracta d'un relat, per tant, amb un final obert que presenta diverses ocasions que poden resultar iròniques i amb un títol que pot esdevenir una pista interpretativa del relat: «el paper del títol a l'obra de Monzó és imprescindible per a copsar el sentit d'alguns dels contes. De fet, de vegades, és en el títol on rau la clau humorística del relat» (Traver, 2019, p. 18). El conte en qüestió, a més, permet observar el bagatge cultural i la capacitat de l'alumne per a interceptar els clixés i la crítica social: «les coses, en l'esfera del desig, tan bon punt s'aconsegueixen deixen d'interessar» (Balaguer, 1997, p. 83). Al relat «¿Perquè 
les busques dels rellotges giren en el sentit de les busques dels rellotges?» s'exemplifica el comportament que anomena Balaguer:

\begin{abstract}
Un home no només s'ha afartat de la seva amant, sinó que sol-licita ajuda per a desprendre's d'ella. El component irònic i humorístic ve determinat pel fet que a qui demana desesperadament consell l'home és, paradoxalment, el marit de la seva amant. El marit, per la seva banda, no només no s'estranya de la petició de l'home, sinó que, a més, li dona el consell "casa-t'hi". (Traver, 2019, p. 33-34)
\end{abstract}

En relació amb l'argument del conte, per tant, s'optà per plantejar diverses preguntes de comprensió lectora que revelaven diferents nivells interpretatius de l'estudiant:

Taula 1. Relació de les preguntes de la comprensió lectora amb els nivells interpretatius treballats

\begin{tabular}{|c|c|c|}
\hline Núm. & Pregunta & Pretén comprovar de l'aprenent: \\
\hline 1 & Resumeix amb tres línies l'argument del conte. & \multirow{2}{*}{$\begin{array}{c}\text { Capacitat de comprensió literal del } \\
\text { text }\end{array}$} \\
\hline 4 & Què t'ha sorprès del conte? Per què? & \\
\hline 2 & $\begin{array}{l}\text { Què vol dir el marit a l'amant de la seva esposa amb } \\
\text { el consell final? }\end{array}$ & \multirow{2}{*}{ Capacitat interpretativa o inferencial } \\
\hline 5 & $\begin{array}{l}\text { Quina relació creus que pot tenir el títol amb el } \\
\text { conte? }\end{array}$ & \\
\hline 3 & $\begin{array}{l}\text { Subratlla en el text una situació que et sembli irònica } \\
\text { i explica per què creus que ho és. }\end{array}$ & \multirow{2}{*}{ Capacitat reflexiva } \\
\hline 6 & $\begin{array}{l}\text { Quina creus que és la intenció o el propòsit que l'au- } \\
\text { tor vol transmetre al lector amb aquest conte? }\end{array}$ & \\
\hline
\end{tabular}

A continuació de l'activitat de comprensió lectora, es plantejà un qüestionari breu a l'alumnat amb la finalitat de descobrir-ne els hàbits lectors (el grau d'importància de la lectura, el tipus de lectura que més i menys els agradaven, l'estona que dedicaven a llegir setmanalment, etc.), comprovar si sabien què era la ironia i com es podia identificar i escatir les preguntes de la comprensió lectora que els havien resultats més fàcils i més difícils.

Per últim, pel que fa a les entrevistes als docents, s'optà per fer-los deu preguntes de resposta oberta a partir de les quals poguessin mostrar la seva visió pel que fa al concepte d'ironia, als hàbits lectors dels estudiants, a la capacitat dels estudiants per a comprendre els sentits no literals i la ironia, als motius que podien deduir de la dificultat dels aprenents per a comprendre la ironia i a allò que es podria fer per millorar la capacitat interpretativa dels aprenents.

\title{
Procés de recollida de dades
}

Pel que fa a les dades obtingudes a partir de les respostes dels estudiants, les activitats de comprensió lectora i els qüestionaris sobre hàbits lectors es dugueren a terme en format paper, amb respostes manuscrites i en una mateixa sessió per cadascun dels grups. El temps aproximat per completar totes dues activitats fou d'entre 30 i 45 minuts: a mesura que l'edat dels alumnes augmentava, l'estona que tardaven a completar les activitats disminuïa. A continuació es mostra la distribució temporal de la recollida de dades: 
Taula 2. Relació de les accions de recollida de dades, participants i dates

\begin{tabular}{|c|c|c|}
\hline Acció & Participants & Data \\
\hline \multirow{3}{*}{ Repartiment d'autoritzacions a l'alumnat } & $1 \mathrm{rd}$ d'ESO & 12 de febrer de 2020 \\
\hline & $3 r$ d'ESO & 14 de febrer de 2020 \\
\hline & $1 \mathrm{r}$ de batxillerat & 11 de febrer de 2020 \\
\hline \multirow{3}{*}{$\begin{array}{l}\text { Realització de les activitats de comprensió lectora } \\
\text { i enquesta d'hàbits lectors }\end{array}$} & 1r d'ESO & 17 de febrer de 2020 \\
\hline & $3 r$ d'ESO & 26 de febrer de 2020 \\
\hline & 1r de batxillerat & 26 de febrer de 2020 \\
\hline \multirow{3}{*}{ Entrevistes al professorat } & Docent 1 & 18 de febrer de 2020 \\
\hline & Docent 2 & 25 de febrer de 2020 \\
\hline & Docent 3 & 27 de febrer de 2020 \\
\hline
\end{tabular}

Cal fer una observació important que pot haver influït en la qualitat de les respostes de, sobretot, l'exercici de comprensió lectora: en cadascun dels grups, es demanà als alumnes que procuressin resoldre l'activitat de forma individual, condició imprescindible per poder expressar la interpretació personal i reflexiva que es buscava amb les preguntes, requisit que es complí majoritàriament en els grups de 1 r d'ESO i 1r de batxillerat. Val a dir que, en el cas dels alumnes de $3 r$ d'ESO, malgrat que l'execució de la tasca va ser individual i el recordatori constant de la importància d'aquesta premissa, hi havia una certa tendència generalitzada a compartir i contrastar les respostes amb els companys.

Per altra banda i pel que fa a les entrevistes amb el professorat, es dugueren a terme en el centre a les hores d'esbarjo, de manera oral i enregistrades. El temps aproximat de durada de cada entrevista va ser d'entre 30 i 40 minuts. Cal comentar que, malgrat que les entrevistes estaven guiades per unes preguntes obertes, s'hi van incorporar qüestions addicionals en cas que la conversa així ho requerís.

\section{Anàlisi de les dades}

El buidatge de les respostes de comprensió lectora es va fer en tres documents d'Excel, un per a cada grup-classe. A continuació, i tenint en compte que es tracta de respostes qualitatives i obertes, es construí una rúbrica per garantir la fiabilitat i l'objectivitat avaluativa -talment com si es tractés d'una activitat de comprensió lectora a l'aula- que contenia diferents criteris i categories establertes a priori, a partir de les expectatives, per a classificar i categoritzar les respostes dels estudiants. En les preguntes que permetien un nombre limitat de respostes o interpretacions vàlides, els criteris de codificació de les respostes eren més tancats. És el cas, per exemple de «Resumeix amb tres línies l'argument del conte» o «Quina creus que és la intenció o el propòsit que l'autor vol transmetre al lector?». En canvi, les preguntes més aviat valoratives o que oferien un nombre més gran d'interpretacions, sempre que fossin justificades i raonades, les categories per classificar les respostes eren més obertes i permissives, com en el cas de "Què t'ha sorprès del conte? Per què?». Un cop establerts els criteris de classificació, es procedí a la lectura i codificació de totes les respostes dels alumnes en tres categories generals: respostes correctes, respostes incorrectes i respostes nul-les o en blanc. A partir d'aquestes dades, es 
calcularen els percentatges que cadascuna de les categories representava per pregunta i grup-classe.

L'anàlisi de les respostes del qüestionari d'hàbits lectors es dugué a terme amb el mateix procediment que l'anàlisi de les comprensions lectores, però amb la diferència que les categories de codificació eren emergents -és a dir, s'establiren a posteriori de l'observació de les respostes-i, en general, més limitades, atès que no es tractava de respostes interpretatives, sinó que presentaven un cert patró que permetia classificar-les en categories més tancades. Per exemple, en la pregunta «Quanta estona dediques a llegir setmanalment?», les categories s'organitzaven en intervals: la categoria A responia a una lectura setmanal d'una hora o inferior, la categoria $B$ responia a una lectura setmanal d'entre una i tres hores, i així successivament. En les preguntes més obertes del qüestionari d'hàbits lectors, com ara «Quin és el tipus de lectura que menys t'agrada» o «Què és la ironia?», es formà una categoria per cada resposta donada i es comptaren les vegades que sortia repetida. Amb els resultats es calcularen els percentatges que cadascuna de les categories representaven per pregunta i grup-classe i, en el cas de les respostes amb un nombre més gran de categories, es tingueren en compte les quatre respostes més repetides per cada nivell.

Per últim, pel que fa a l'anàlisi de les entrevistes, un cop transcrites de la llengua oral al suport escrit, es classificaren les respostes prenent com a unitat d'anàlisi cadascuna de les preguntes. Així, s'elaborà quadre-resum amb la col-lació dels conceptes clau expressats pels professors en cadascuna de les preguntes, el qual permetia comprovar la diversitat o concordança entre les respostes. Així, malgrat la singularitat de les respostes, a partir de les idees expressades en cada pregunta, es creà una síntesi amb les idees més comunes a tall de conclusió general que representa la visió del professorat a grans trets.

\section{Resultats de l'estudi}

\section{Resultats de la tasca de comprensió lectora}

Per començar, s'analitzen els resultats de les preguntes 1 i 4, les quals requerien una comprensió literal del text. La primera pregunta de l'exercici de comprensió lectora, consistent en resumir l'argument del conte (taula 3), és la que posseeix un índex més elevat de respostes correctes en tots tres cursos i, a més, el percentatge d'encerts augmenta a mesura que s'incrementa el nivell dels alumnes. Mentre que la pregunta 1 admetia una resposta completament literal, la pregunta 4, en la qual es demanava als alumnes allò que més els havia sorprès del conte, requeria, a més, una part de raonament i justificació de la tria. Per tant, traspassar aquesta barrera estrictament literal, que ha afegit més complexitat a la pregunta, ha afectat el percentatge de respostes encertades. Mentre que l'índex d'encerts a batxillerat es manté prou alt, amb un 75\%, a $1 \mathrm{r}$ i a $3 \mathrm{r}$ d'ESO han disminuït a un $47 \%$ i $46 \%$ respectivament, per la qual cosa el percentatge d'encerts entre aquests dos cursos es manté estable. 


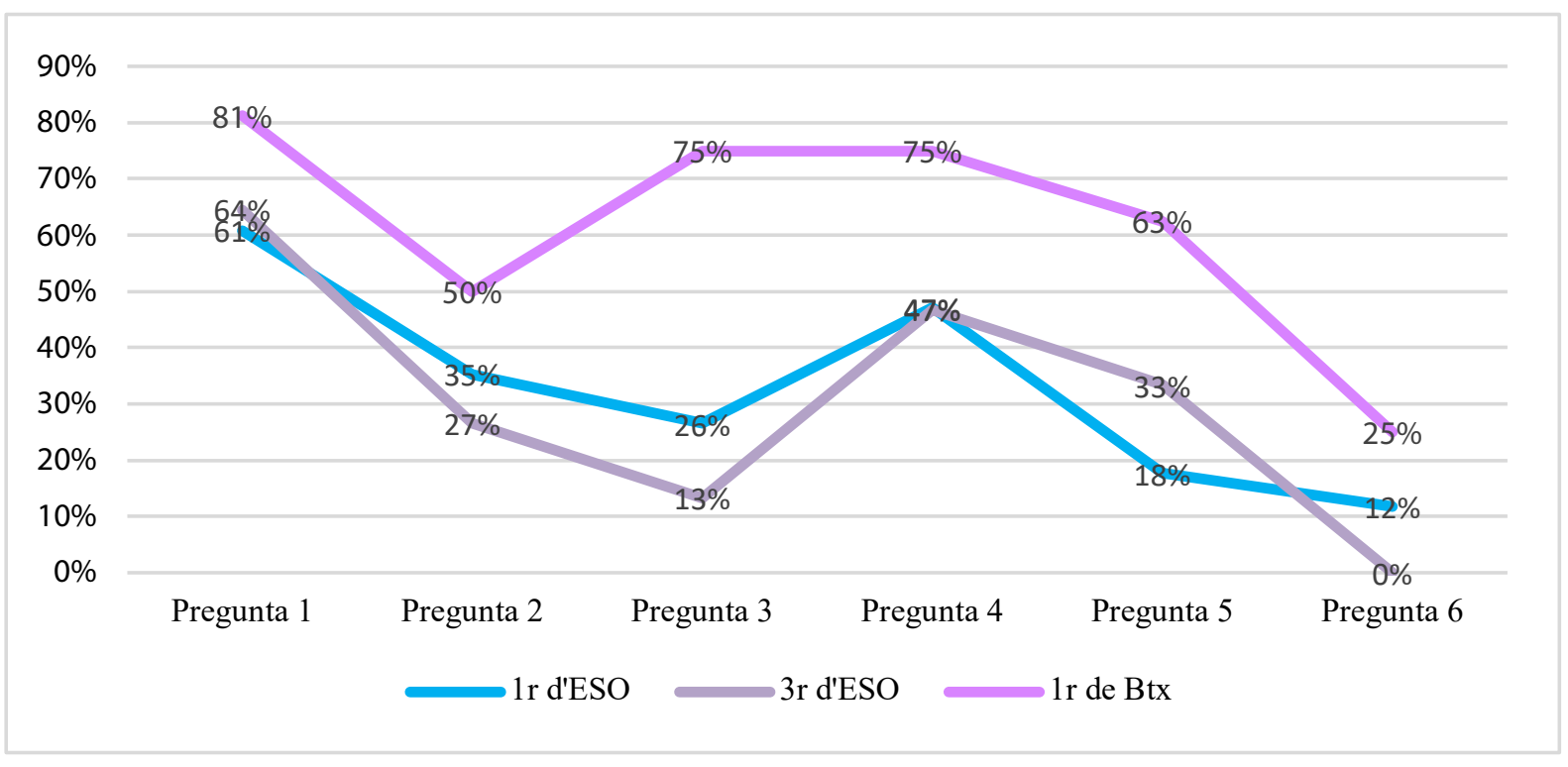

Si hom es fixa en les preguntes inferencials, 2 i 5, es fa palès que el procés interpretatiu en la comprensió lectora passa factura a tots els nivells (taula 3), amb un índex d'encert del $35 \%$ a $1 r$ d'ESO, del $26 \%$ a $3 r$ d'ESO i del $50 \%$ a $1 r$ de batxillerat en la segona pregunta, consistent en traspassar la barrera literal i revelar el missatge entre línies d'un dels personatges del relat. Cal observar, per tant, que ha estat el nivell mitjà, de $3 r$ d'ESO, el que ha respost de manera menys encertada. Pel que fa a la cinquena pregunta, en la qual els alumnes havien de cercar una possible interpretació que expliqués el contingut del títol amb el del relat, tan sols s'ha obtingut un $17 \%$ d'encerts a $1 \mathrm{r}$ d'ESO, amb una pujada del $33 \%$ d'encerts a $3 r$ d'ESO i un $62 \%$ a $1 r$ de batxillerat. En aquest cas, es torna a observar una tendència gradual: I'increment de l'edat dels alumnes afavoreix els encerts.

Per últim, cal fixar-nos en aquelles preguntes, 3 i 6, que requerien una capacitat lectora més reflexiva. Els resultats de la tercera pregunta són aquells que presenten uns percentatges més contrastats pel que fa als diferents nivells (taula 3). Així, mentre que els alumnes de batxillerat, amb un 75\% d'encerts, han estat capaços d'identificar i justificar una expressió irònica del text, pel que fa als alumnes de $1 \mathrm{r}$ i $3 \mathrm{r}$ d'ESO, tan sols ho han fet correctament un $26 \%$ i un $13 \%$, respectivament. Els resultats de l'última pregunta, relativa al propòsit de l'autor, han estat els més baixos per tots tres nivells pel que fa al nivell d'encerts, amb tan sols un $11 \%$ a $1 r$ d'ESO, un $0 \%$ a $3 r$ d'ESO i un $25 \%$ a $1 r$ de Batxillerat. En les preguntes de caràcter reflexiu no s'ha vist cap mena d'evolució gradual dels encerts: mentre els alumnes de $1 r$ de batxillerat encapçalen indiscutiblement el nombre de respostes correctes, els alumnes de $1 \mathrm{r}$ d'ESO obtenen millors resultats que els de $3 r$ en aquesta categoria.

La mitjana de respostes encertades per 1r d'ESO és del 33\%, a 3r d'ESO és del 30\% i a $1 \mathrm{r}$ de batxillerat és del $61 \%$.

\section{Resultats del qüestionari}

En la taula 4 es poden observar els percentatges pel que fa al gust per la lectura de l'alumnat, en tant que (A) mostra els estudiants que els agrada llegir, (B) els que els agrada una mica o depenent del tipus de lectura i (C) els estudiants que no els agrada llegir. Es pot 
observar que el percentatge més alt d'alumnes que els agrada llegir correspon al grup de 1r d'ESO, seguit de $1 r$ de batxillerat i, per últim 3r d'ESO.

\section{Taula 4. Gust per la lectura}

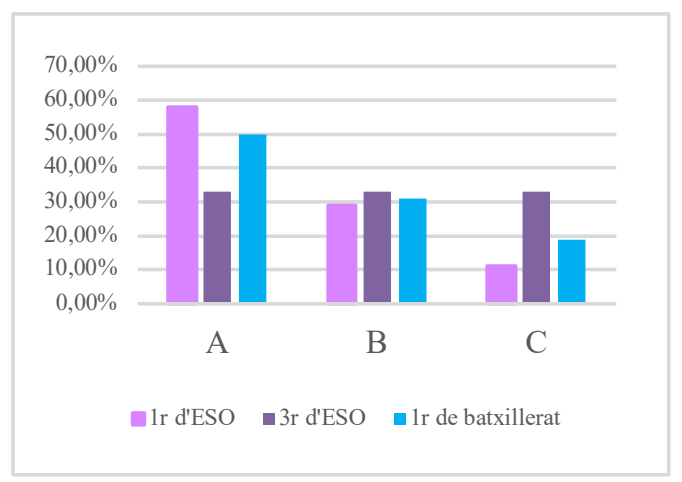

Taula 5. Importància de la lectura diària

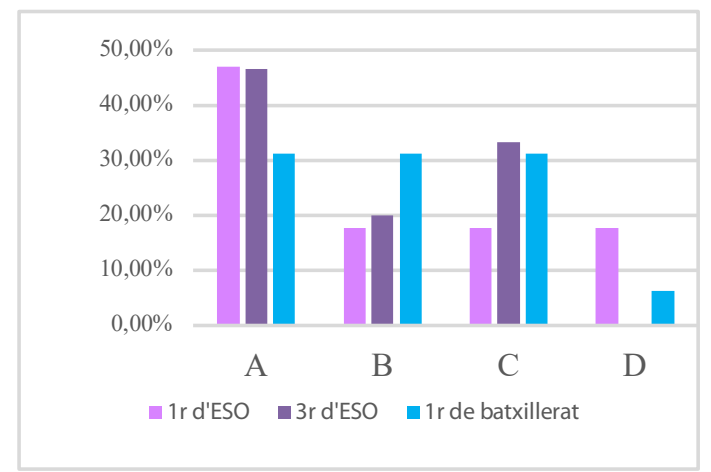

Pel que fa a la importància que té per als alumnes la lectura en el seu dia a dia (taula 5), observem que la categoria $(A)$, majoritària, mostra que gran part d'alumnes de $1 \mathrm{r}$ i $3 \mathrm{r}$ d'ESO consideren que la lectura és important en el seu dia a dia. En la categoria (B) es mostren els alumnes que consideren la lectura relativament important $i$, per últim, els que consideren que és poc important (C). Al seu torn, la categoria (D) correspon a una pregunta no resposta, nul.la o que no especifica el grau d'importància de la lectura per a l'estudiant. Veiem, per tant, una certa tendència a l'alça de l'alumnat de $1 \mathrm{r}$ d'ESO pel que fa a la importància diària de la lectura en comparació amb uns nivells més distribuïts en totes tres categories en els cursos de $3 r$ d'ESO i $1 r$ de batxillerat.

La taula 6 mostra l'autoconcepció que tenen els alumnes envers la facilitat per a comprendre els textos que llegeixen. Els alumnes de $1 \mathrm{r}$ d'ESO tenen el percentatge més elevat $-52 \%$ - de percepció de facilitat per a comprendre els textos $(A)$ i, en canvi, uns índexs inferiors -23\%- de facilitat de comprensió ocasional (B) i de poca facilitat de comprensió (C) $-23 \%-$. Els resultats en els alumnes de $3 r$ d'ESO i $1 r$ de batxillerat són més equilibrats: la majoria se situa entre la categoria $(A)$ i $(B)$, és a dir, entre un bon nivell i un nivell mitjà de facilitat per a comprendre els textos, amb una suma d'un $93 \%$ i un $87 \%$ respectivament.

Taula 6. Facilitat per a comprendre textos

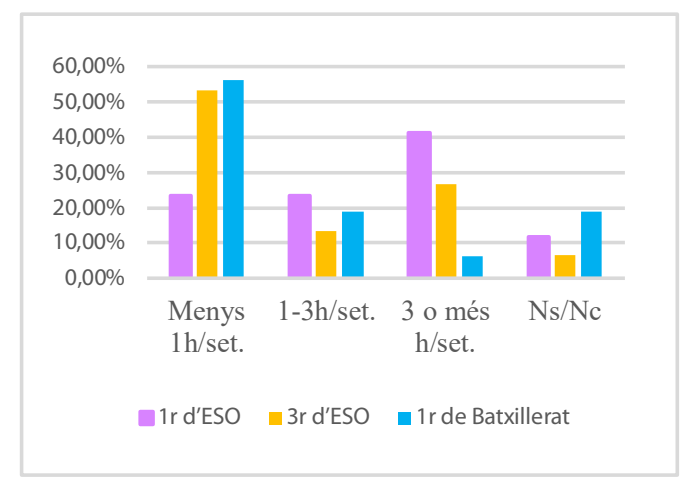

Taula 7. Estona de lectura setmanal

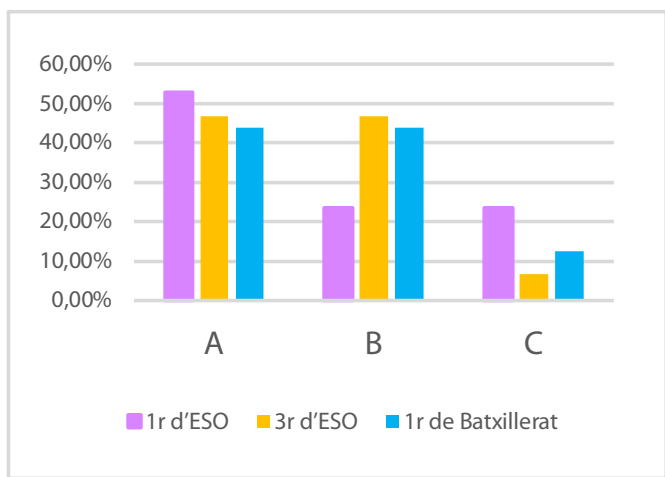

La taula 7 mostra l'estona que dediquen els alumnes a la lectura de manera setmanal. El percentatge més alt d'alumnes de $3 r$ d'ESO i $1 r$ de batxillerat llegeix menys d'una hora a la setmana. Els resultats de $1 \mathrm{r}$ d'ESO, en canvi, són més estables, amb una tendència a 
I'alça: la major part dels alumnes asseguren que llegeixen durant 3 o més hores setmanals.

Taula 8. Interpretació del significat del concepte ironia

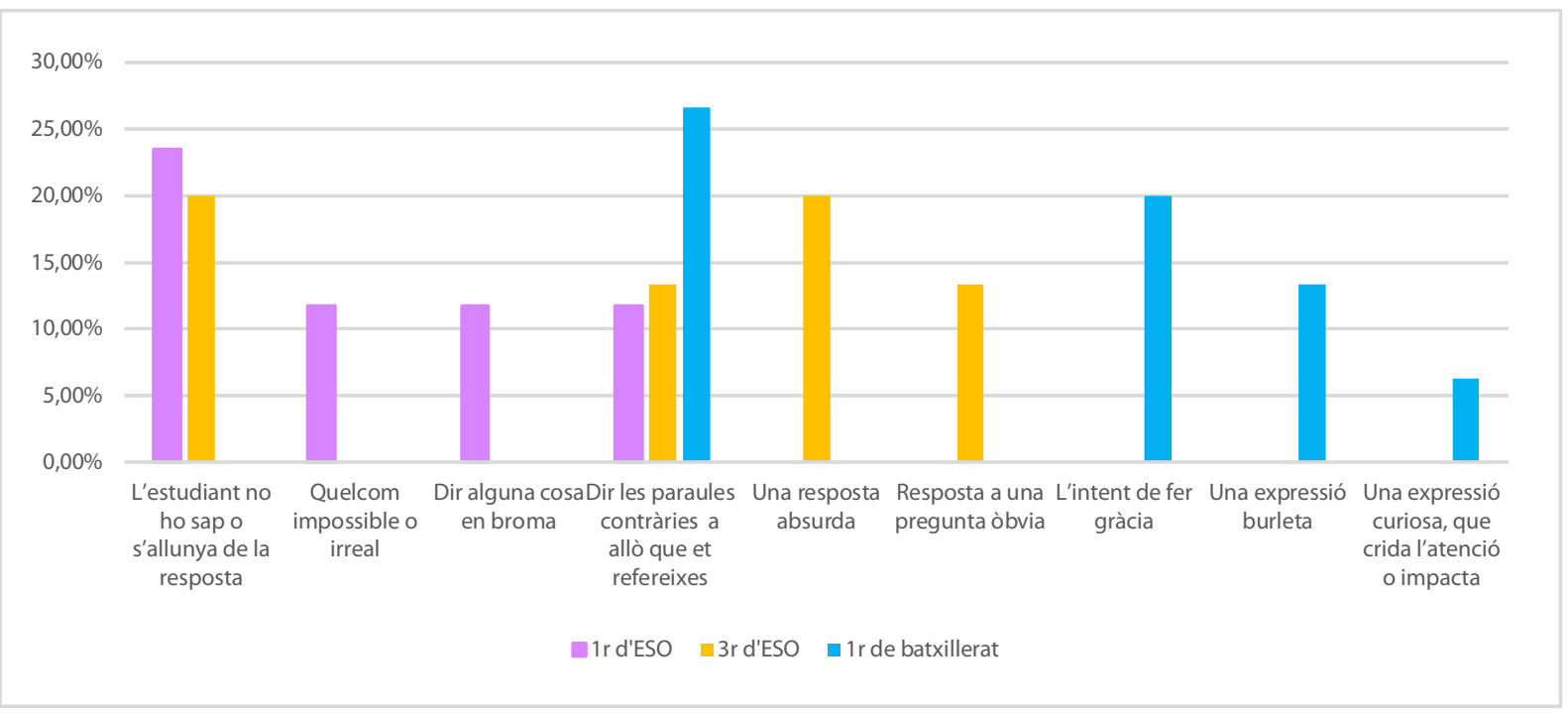

En la taula 8 -la qual, juntament amb la taula 9, mostren els resultats més significatiusqueda copsada la idea dels estudiants envers allò que creuen que és la ironia. Un percentatge alt dels estudiants de 1 r i $3 r$ d'ESO (taula 8) mostra que l'aprenent no ho sabia o la seva resposta s'allunyava massa de l'objectiu de la pregunta. Pel que fa a les respostes més habituals de $1 r$ d'ESO, foren que la ironia és quelcom impossible o irreal, que és dir alguna cosa de broma i que és sinònim a expressar les paraules contràries a allò que hom es refereix.

Bona part dels estudiants de $3 r$ d'ESO i de $1 r$ de batxillerat (taula 8) compartiren aquesta última resposta: la ironia com quelcom contrari a allò que refereix. Una altra part dels resultats de $3 r$ d'ESO apuntaven a la idea d'ironia com a resposta absurda i com a resposta a una pregunta òbvia. D'entre les respostes dels alumnes de $1 r$ de batxillerat hi trobem diverses interpretacions del concepte: I'intent de fer gràcia, una expressió burleta, i una expressió curiosa, que crida l'atenció o que impacta.

En l'altra pregunta relacionada amb la ironia -en concret, sobre com creien els estudiants que es podia identificar en un text-, de nou, una gran part de les respostes de tots tres cursos mostraren la manca de coneixement o de precisió envers la qüestió demanada (taula 9). D'entre les altres respostes dels estudiants de $1 \mathrm{r}$ d'ESO destaca la idea que podem identificar la ironia perquè impacta o crida l'atenció, perquè és una idea seriosa, real o lògica o perquè s'identifica si hom es fixa en el text o expressions dels personatges, idea també expressada pels estudiants de $3 r$ d'ESO, juntament amb la identificació de la ironia com una frase estranya, sense sentit o il.lògica o a partir de fixar-se en la connotació, el to o la manera de dir-se una cosa. Pel que fa als estudiants de $1 \mathrm{r}$ de batxillerat, altres respostes apunten a identificar la ironia segons el context, a partir d'una situació burleta o satírica i, per últim, quan el significat d'un text no s'entén o és contradictori. 
Taula 9. Concepció dels estudiants envers la forma d'identificació de la ironia en un text

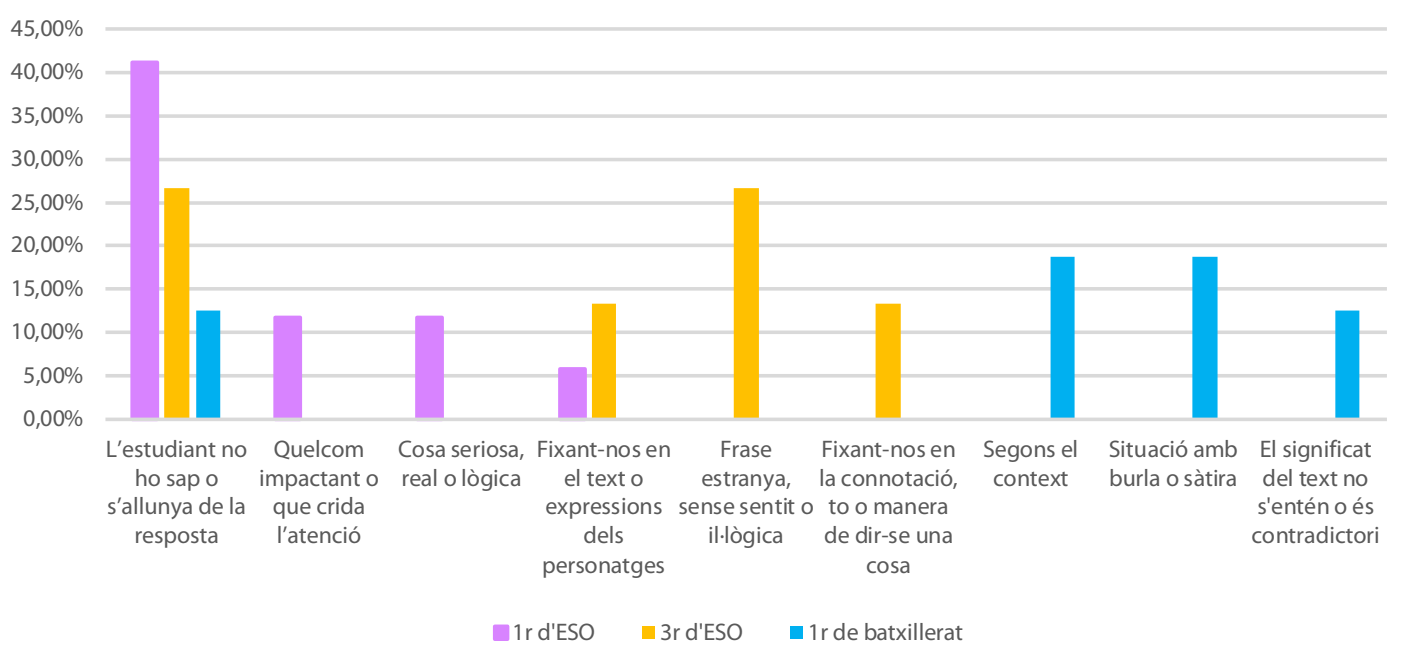

Per últim, pel que fa a les preguntes de l'activitat de comprensió lectora que els resultaren més senzilles de respondre, tots tres cursos coincidiren amb la pregunta 1 en primer lloc i, en segon Iloc, en la pregunta 4, precisament aquelles que requerien una interpretació literal per part de l'alumnat. D'entre les preguntes que els alumnes consideraren més difícils, destaquen la 3 i la 6 per 1r d'ESO -les dues preguntes d'intenció reflexiva-, la 5 i la 6 per $3 r$ d'ESO i la 5 -amb l'objectiu d'establir una relació entre el títol i el conte- per $1 r$ de batxillerat.

\section{Resultats de les entrevistes a docents}

En referència a les diverses concepcions que tenen els diferents professors entrevistats sobre la ironia, el docent 1 creu que es tracta d'una eina elaborada que utilitzem per explicar algun concepte, el docent 2 creu que és gairebé de modus vivendi, un recurs imprescindible i una manera d'entomar les circumstàncies personals d'una manera més amable. El concepte que en té el docent 3 també coincideix amb una de les idees expressades pel docent 1: la ironia va lligada a la intel-ligència de l'individu que l'utilitza.

Pel que fa al gust per la lectura dels estudiants, mentre que els docents 1 i 2 consideren que, en general, als estudiants no els agrada llegir, el docent 3 diu que depèn del cas. Els docents 1 i 2, a més, coincideixen amb el fet que hi ha una pèrdua generalitzada de I'hàbit lector en el pas dels estudiants de primària a secundària i que la lectura està associada a l'avorriment. El docent 3, per la seva banda, considera que hi ha una falta d'atenció general per part dels estudiants, però recorda que llegir no només significa la lectura d'obres literàries.

Sobre la reacció dels estudiants davant dels sentits no literals o d'aquelles lectures que requereixen una interpretació o reflexió més desenvolupada, els docents 1 i 3 convergeixen en la idea que als alumnes els fa mandra pensar. Mentre que el docent 3 associa aquesta mandra a la dificultat dels alumnes per reflexionar de manera autònoma que els fa cercar constantment pistes en el professor, el docent 1 creu que es tracta d'una qüestió de manca de voluntat per treballar i, per tant, de reticència envers la percepció dels sen- 
tits no literals o a l'intent de reflexió. El docent 2, qui es refereix als estudiants de batxillerat, assegura que en l'etapa d'escolarització postobligatòria els aprenents ja tenen prou eines per interceptar amb èxit els sentits no literals.

En concret, pel que fa a la comprensió de la ironia, els docents 1 i 3 estan d'acord en el fet que, en general, els alumnes d'ESO no la solen comprendre o els costa treure'n conclusions. En el cas dels estudiants de batxillerat, en canvi, el docent 2 afirma que solen comprendre-la, malgrat que de vegades els costi. Ara bé, l'acompanyament del professor resulta imprescindible. En relació amb la causa, el docent 1 assegura que als estudiants els costa comprendre la ironia perquè s'ha perdut la capacitat de pensar i els aprenents esperen que el professor faci l'esforç per ells i, en canvi, el docent 3 vincula la problemàtica al fet que es requereix un bagatge lingüístic prou ampli, i que sovint encara no posseeixen els alumnes d'ESO, per a comprendre-la reeixidament.

Quan se'ls preguntà als professors què creien que es podria fer per millorar la capacitat interpretativa lectora dels estudiants, en general coincidiren: caldria potenciar I'hàbit lector de l'alumnat. Els docents 1 i 3 apostarien per la implantació d'un pla lector de centre. Com a mesures d'actuació addicionals, el docent 1 es decanta per l'acompanyament als alumnes en l'òptima tria de les lectures i en la tasca de la família com a element clau per a fomentar l'hàbit lector dels estudiants i el docent 3 aposta per confiar en la constància i regularitat d'un pla lector, és a dir, amb els resultats a llarg termini, i amb el fet de combinar lectures de la literatura clàssica amb obres més amenes per tal de fidelitzar als estudiants a la lectura. La visió del docent 2, per altra banda, és més pessimista: comenta que no es pot fer gaire res al respecte a curt termini per tal que la capacitat interpretativa dels alumnes millori, atès que caldria que l'educació en general fos més exigent pel que fa al bagatge cultural, al coneixement de l'entorn i a la capacitat d'expressió i comprensió de l'alumnat, el qual es potenciaria amb un nombre més elevat d'assignatures humanístiques en el currículum educatiu.

Per últim, pel que fa al paper de les tecnologies i el món audiovisual en els hàbits lectors dels estudiants, hi hagueren tres visions ben diferenciades: el docent 1 considera que les tecnologies són la causa principal de la falta d'atenció de l'alumnat, atès que l'estona davant d'una pantalla desplaça el temps davant d'un llibre. Considera, a més, que l'entreteniment passiu ha passat factura a la capacitat de pensar dels estudiants. El docent 3 assimila la cultura audiovisual com a una alternativa d'entreteniment pels lectors menys habituals o com una mena de crossa per la mandra lectora dels estudiants, a qui resulta més fàcil visualitzar una pel-lícula que prestar atenció a un llibre. Per últim, el docent 2 opina que els adolescents desplacen la lectura per se i, per tant, la tecnologia pot substituir l'estona dedicada a la lectura, tal com ho poden fer altres formes d'entreteniment.

\section{Discussió dels resultats}

En aquest apartat es reprenen les preguntes formulades per tal de respondre-les a partir dels resultats presentats. Vegem-los, doncs, en relació amb els tres processos fonamentals en la comprensió i interpretació dels textos: precisament, les preguntes que requerien una resposta de comprensió literal -preguntes 1 i 4- han estat aquelles que han tingut millors resultats (taula 3): en la pregunta 1 hi ha hagut un alt percentatge d'encerts en tots tres grups. La pregunta 4, malgrat que el nombre d'encerts és inferior, sobretot a $1 r$ i $3 r$ d'ESO -segurament perquè demanava, a més de la comprensió literal, una part 
valorativa-, representa la segona pel que fa a la quantitat d'encerts entre l'alumnat. Per tant, en general els aprenents de l'estudi dominen prou bé la comprensió dels sentits literals del text.

Ara bé, en les respostes de les preguntes 2 i 5 -les quals requerien un procés no només de comprensió, sinó d'interpretació textual- es fa palès un descens important del nombre d'encerts respecte a les preguntes 1 i 4 . Si hom compara el percentatge d'encerts de totes dues preguntes inferencials, s'evidencia que els alumnes de $1 r$ d'ESO els costa menys interpretar i explicar amb les seves paraules una informació literal del text (pregunta 2) que no pas establir una relació entre el títol i el contingut o missatge del conte (pregunta 5). Paradoxalment, i al contrari, els alumnes de $3 r$ d'ESO i de $1 r$ de batxillerat han obtingut un nombre més alt d'encerts en la pregunta 5 que en la pregunta 2, amb un $26,66 \%$ i un $50 \%$ respectivament. En el cas que ens ocupa, com en tants altres contes de Monzó, el títol esdevé un element interpretatiu potencial. Emfasitzar en el paper del títol no només ens ajuda a posar a prova la capacitat de l'alumnat de relacionar dos fragments superficialment diferenciats, sinó que, alhora, guia a l'estudiant a copsar el sentit del text:

\footnotetext{
En moltes ocasions, el títol de l'obra es converteix en un recurs fonamental en la construcció del sentit, utilitzat de forma deliberada i perfectament planificada per part de l'autor. Aquesta mena de valor estratègic del títol és particularment rellevant en les formes narratives breus (conte i nouvelle), l'escriptura de les quals es troba governada pel principi d'economia, cosa que determina una explotació màxima de tots els recursos a l'abast, ja que la narració no pot avançar en extensió i ho ha de fer en intensitat, fent valdre de manera molt productiva, com a instruments, els implícits i la creació/trencament d'expectatives. (Gregori, 2011, p. 1)
}

El fet que els alumnes més grans trobin amb més facilitat relacions o vincles entre títol i conte podria atribuir-se, precisament, al grau d'experiència: «Sembla, en moltes ocasions, que els més novells no són capaços de reconèixer la connexió existent entre els diferents paràgrafs i, així, no hi poden establir relacions causa-efecte, fet que sí que s'entreveu en els més experts» (Sacristán, 2006, p. 141-142). Aquesta dificultat per establir relacions entre diverses parts d'un mateix text, la qual té a veure amb l'edat de l'alumne, va lligada amb la següent afirmació de Sacristán, basada en els resultats d'un estudi comparatiu de comprensió lectora amb alumnes de diferents edats, en la qual:

\footnotetext{
En els lectors de menor edat, i per això, en principi, més novells, els processos de lectura són més simples, immadurs i en alguns casos incomplets; els lectors de major edat, per contra, teòricament més experts, fan una lectura que implica processos cognitius més complexos, adequats i profunds. (Sacristán, 2006, p. 141142)
}

Aquests processos de lectura més simples i incomplets coincideixen amb la dificultat que presenten alguns alumnes de $3 \mathrm{r}$ d'ESO a I'hora de donar resposta a una pregunta interpretativa sobre un text: «Cada vegada que dic que aquesta pregunta pot tenir més d'una resposta bona, això no els agrada. [...] Hi ha aquesta por de sortir del que posa tothom, [...] de posar una cosa diferent. I això [...] es va repetint any rere any, per tant és una por compartida» (docent 3, torn 22). Aquesta actitud per part de l'alumnat es féu palesa durant la realització de l'activitat de comprensió lectora: els alumnes de 3r d'ESO foren I'únic grup amb dificultats per no compartir i contrastar les seves respostes amb els companys. Aquest fet va influir, probablement, amb els resultats de l'estudi: prova n'és que 12 alumnes dels 15 participants d'aquest grup assenyalaren el mateix fragment irònic en la pregunta 3, relacionada amb la identificació i justificació d'un fragment irònic en el text. En aquesta pregunta, el nombre de respostes correctes a $1 r$ d'ESO és del $26 \%$, a $3 r$ d'ESO és del $13 \%$ i a $1 \mathrm{r}$ de batxillerat és del $75 \%$. Per tant, s'observa que el percentatge 
d'encerts en la pregunta directament relacionada amb la ironia descendeix respecte a la mitjana de respostes encertades al grup de $1 \mathrm{r}$ i $3 \mathrm{r}$ d'ESO - un 7\% i un 17\% respectivament- $i$, en canvi, ascendeix en el grup de $1 r$ de batxillerat un $13 \%$.

Així doncs, es mostra clarament com la localització i interpretació de la ironia representen un dels punts febles en l'activitat de comprensió lectora dels alumnes de $1 r$ i $3 r$ d'ESO i, en canvi, s'observa un cert domini dels estudiants de batxillerat pel que fa a la interpretació irònica. La percepció dels docents entrevistats sosté, també, aquesta afirmació: pel que fa a l'alumnat d'ESO, «davant d'un sentit figurat o d'una frase feta moltes vegades no saben arribar a les conclusions» (docent 1, torn 30), fet que pot tenir a veure que «els fa molta mandra pensar, estan acostumats a trobar-s'ho tot fet i, és clar, la ironia demana la teva interpretació i això no els agrada» (docent 1, torn 26). La visió del docent 3 pel que fa a la dificultat de comprensió de la ironia, en canvi, apunta més aviat a la manca d'un bagatge prou complet en relació amb l'edat dels estudiants, en la mateixa línia dels arguments de Zamorano (2015, p. 47), qui recalca la importància del coneixement i domini de la informació contextual, necessaris per interceptar la ironia, i de Roca (2009), qui matisa l'ús cultural, i no només lingüístic, del recurs: «La ironia és un grau bastant elevat en el nivell de comprensió de textos. Has de tenir la part contextual ben assumida, per això un noiet de 10 anys o de 12, de primer d'ESO, és lògic que no capti les ironies, potser les més senzilles sí o alguna ironia de nivell zero» (docent 3). El professor, per tant, normalitza a priori el poc èxit en els hipotètics resultats de $1 \mathrm{r}$ d'ESO pel que fa a la comprensió de la ironia: «no m’alarmaria si és que no són gaire positius» (docent 3, torn 28) els resultats obtinguts en l'activitat, atès que, assegura, per comprendre reeixidament la ironia cal haver passat per un procés de coneixement més ampli de la llengua, cal adquirir un bagatge lèxic: «si no coneixen els quatre nivells de llengua, [...]imagina't amb la ironia, la ironia és jugar una lliga a part» (docent 3).

De fet, tal com assegura el professor, no hauria de resultar estrany que els alumnes de, sobretot, 1r i 3r d'ESO no hagin excel-lit, precisament, en la identificació de la ironia en el relat: quan se'ls preguntà en el qüestionari d'hàbits lectors: «Què és la ironia?», la resposta més repetida en tots dos cursos, amb un $23 \%$ i un $20 \%$ respectivament (taula 8 ), era que l'estudiant no ho sabia o bé s'allunyava massa de la resposta. Les segones i terceres opcions més freqüents, encara que poden apropar-s'hi en alguns aspectes, tampoc acaben de perfilar amb exactitud el concepte: la ironia vista com a quelcom impossible o irreal o com a sinònim d'una broma -1r d'ESO-; com una contesta absurda o una resposta a una pregunta òbvia -3r d'ESO-. No és fins a la quarta opció -amb un 11\% i un 13\% respectivament- que les respostes de l'alumnat apunten amb més precisió a la definició del concepte: la ironia consisteix a dir les paraules contràries o oposades a allò que hom es refereix o a allò que és lògic. A més a més, també se'ls preguntà «Com creus que podem identificar la ironia en un text?». De nou, el percentatge més alt de respostes apunten a la desconeixença, amb un $41 \%$ a $1 r$ d'ESO i un $26 \%$ a $3 r$ d'ESO (taula 9).

Així doncs, amb un índex tan reduït d'alumnes que comprenen el significat del terme i la forma d'identificació, no resulta estrany, per tant, que pocs estudiants hagin estat capaços de localitzar i justificar reeixidament una expressió irònica en el conte: només hi ha un $26 \%$ de respostes correctes a $1 \mathrm{r}$ d'ESO i tan sols un $13 \%$ a $3 \mathrm{r}$ d'ESO, percentatge que, en aquest segon cas, coincideix amb exactitud amb el nombre d'alumnes que en el qüestionari d'hàbits lectors demostraren que comprenien el significat del terme ironia. 
Després dels discrets resultats dels alumnes de $1 \mathrm{r}$ i 3 r d'ESO en la pregunta 3, cal observar l'altre extrem: els estudiants de $1 \mathrm{r}$ de batxillerat obtingueren un $75 \%$ d'encerts, amb una diferència significativa - $d$ 'un $49 \%$ i d'un $62 \%$ respectivament- envers els grups de 1 r i 3 r d'ESO. La majoria d'alumnes no només detectaren en el text fragments que, en relació amb l'argument i el context, podrien interpretar-se com a irònics, sinó que, a més, ho justificaren reeixidament. Els resultats positius dels alumnes de batxillerat coincideixen amb la percepció que té el docent 2 -qui és professor del grup en qüestió- de la capacitat interpretativa de la ironia dels seus alumnes: «han passat per tot el sistema educatiu i, en general, han desenvolupat habilitats per gestionar-ho [reacció dels estudiants davant dels sentits no literals o que requereixen interpretació]. No crec que es perdin majoritàriament el sentit de les coses si els hi poses bastant senzill» (docent 2). El professor atribueix també la capacitat interpretativa al bagatge cultural i lingüístic: «els sentits no literals els poden captar o no si tenen prou coneixements i prou vocabulari i la ironia la capten igual si li dones [a l'alumne] prou marge, prou peu a entendre que allò té un sentit irònic. Però els has d'ajudar, evidentment» (docent 2). Cal notar que, malgrat que el professor fa èmfasi en l'acompanyament del docent com a eina essencial per tal que I'alumnat pugui copsar el sentit irònic d'una frase o text, l'alumnat ha obtingut en la comprensió lectora un 75\% d'encerts en la pregunta 3 sense cap mena d'ajuda, comentari o directriu prèvia a l'activitat. Per tant, malgrat que la visió del professor envers la interpretació de la ironia és més positiva que la dels altres professors en l'alumnat d'ESO, els resultats demostren que els estudiants de batxillerat són prou competents i, per tant, presenten més autonomia de la percebuda pel docent. Ara bé, cal tenir en compte que les característiques del relat -farcit d'estereotips i clixés socials, amb uns personatges amb rols conductuals poc habituals- pretenien cridar l'atenció de l'alumnat i fomentar la seva capacitat reflexiva a través d'un argument que, pres literalment i en el seu context, resultava gairebé inversemblant. El docent 2 corrobora que un factor que sol facilitar la comprensió irònica dels alumnes és que en el text «hi hagi algun element, informació no verbal que els doni peu a entendre que allò que dius ho han d'entendre de manera no estrictament literal. Si tu no dones peu que facin el pas d'intentar trobar un altre sentit, llavors, és més complicat» (docent 2). Ara bé, aquest fet no implica que s'hagi de desmerèixer la tasca dels alumnes de batxillerat: mentre que la majoria d'alumnes de $1 \mathrm{r}$ i $3 r$ d'ESO mostraren una concepció desdibuixada del significat d'ironia a partir de les respostes del qüestionari d'hàbits lectors, els alumnes de batxillerat expressaren idees prou encertades: un $26,66 \%$ de les respostes apuntaven que la ironia era dir les paraules contràries o oposades a allò que hom es refereix o a allò que és lògic, un 20\%; a una expressió burleta i un 13,33\%; a l'intent de fer gràcia. Per tant, en les respostes els estudiants no només demostren un coneixement prou ampli del que significa el concepte de manera formal, sinó que, a més, n'intuïren el propòsit o intencionalitat. Aquestes percepcions, per tant, demostren que la tria del conte ha estat encertada, que ha complert la seva funció i que s'ha establert una connexió bidireccional entre l'autor -l'emissor- i l'alumne -el receptor-, de manera que ha esdevingut conscient de la proposta gràcies al text, vehicle de transmissió: «el reconocimiento intuitivo que los lectores hacen de conceptos como el humor, el sarcasmo o la sátira nos hacen pensar en una ironía continuada que ha dado en el blanco perlocutivo: provocar risa y, a la vez, reflexión» (Caro, 2017, p. 107).

Si hi ha una cosa clara és que es fa palesa una evolució notable entre els resultats d'alumnes d'ESO i de batxillerat pel que fa a la qualitat de les respostes de tota l'activitat de comprensió en general i en la interpretació de la ironia en particular. Si bé, doncs, es pot establir un evident patró evolutiu ascendent i qualitatiu entre els estudiants d'ESO i 
els estudiants de batxillerat, l'hipotètic progrés entre 1 r i 3r d'ESO queda més difuminat en l'estudi que ens ocupa, de manera que les característiques de cadascun dels grups i del procés de recollida de dades no s'han traduït a un patró creixent d'encerts en concordança amb l'edat creixent de l'alumnat. Així, en algunes preguntes el nombre d'encerts ha estat superior a 3r d'ESO i, en altres, a 1r d'ESO. Per tant, això fa pensar que la capacitat de vincular reeixidament els coneixements previs amb el contingut textual per a establir relacions coherents i extreure'n una posterior reflexió, tal com explica Villarrubia, no es desenvolupa de forma més evident i consolidada fins a la finalització dels estudis obligatoris de l'estudiant:

De acuerdo con los principios de relevancia, el texto literario da lugar a que el lector busque entre sus conocimientos que le sirven de contexto, ideas que se relacionen con lo que está leyendo. A veces el lector buscará dentro de su universo de conocimientos y no encontrará ningún elemento que le ayude a descifrar o decodificar el sentido del texto. El mensaje será relevante pero el lector no dispondrá de los códigos que le permitan descifrarlo. (Villarubia, 2010, p. 25)

Ara bé, la causa d'aquesta capacitat de comprensió de la ironia mostrada pels alumnes batxillerat en comparació amb els d'ESO no es basa tan sols en la quantitat i qualitat del seu bagatge de coneixements, sinó també amb la capacitat d'integrar-los reeixidament: «els novells no intenten integrar el coneixement que tenen d'altres àrees, mentre que els experts sí que ho fan. Això constitueix una altra raó per què els novells no arriben a una bona comprensió de la lectura» (Sacristán, 2006, p. 141-142). Per tant, tal com hem vist, l'edat i l'experiència de l'alumne són dos elements que juguen a favor de la capacitat interpretativa de la ironia.

Per últim, pel que fa a les dues qüestions reflexives de l'activitat de comprensió, val a dir, però, que el nombre d'encerts en la pregunta 3 són superiors als de la pregunta 6 relacionada amb la intencionalitat de l'autor-, la qual ha obtingut el nombre més baix d'encerts per tots tres grups. Descobrir la intencionalitat de l'autor d'un text representa una de les tasques interpretatives més avançades i complexes. No és estrany, doncs, que a bona part dels alumnes els hagi succeït el mateix que als participants de l'estudi de Caro, qui estaven també exposats a la lectura i interpretació de textos irònics:

Un buen número de lectores pasaron por alto la intención irónica del autor y tropezaron con la construcción del texto base, por lo que se adhirieron, más bien, a algún detalle del código de superficie y juzgaron, a priori, desde el marco situacional, amparados por sus conocimientos previos. (Caro, 2017, p. 113)

Els resultats mostren, en definitiva, que és en el procés reflexiu on els alumnes tenen, generalment, més mancances. El tercer procés fonamental de comprensió lectora, segons el Decret 187/2015, implica «posar en funcionament els coneixements externs del text i previs del lector, requereix saber desenvolupar una comprensió global del text, integrar i deduir-ne la informació no explícita» $(2015$, p. 23), per la qual cosa requereix una competència avançada del primer i del segon procés -lectura literal i inferencial- per a dominar el camp de la reflexió metaliterària.

Ara bé: tenen alguna cosa a veure els hàbits de lectura dels estudiants amb la capacitat interpretativa de la ironia? Vegem-ho. Una de les dades del qüestionari d'hàbits lectors que més relació pot mostrar amb els resultats de la pregunta sobre la ironia de la comprensió lectora és el gust per la lectura dels estudiants. Així, la suma dels alumnes que afirmen que els agrada llegir o que els agrada en certes ocasions, depenent del tipus de lectura, representa un $88 \%$ dels alumnes de $1 \mathrm{r}$ d'ESO, un $66 \%$ dels alumnes de $3 \mathrm{r}$ d'ESO i un $81 \%$ dels alumnes de $1 \mathrm{r}$ de Batxillerat (taula 3). Aquests resultats no concorden amb la visió que tenen els professors respecte al gust per la lectura de l'alumnat: els docents 
1 i 2 afirmen que, en general, als estudiants no els agrada llegir i el docent 3 diu que depèn del cas. Cal tenir en compte, però, que dugueren a terme aquestes afirmacions sense tenir consciència de les respostes de l'alumnat en els qüestionaris i en l'activitat de comprensió lectora. En aquest sentit, aquesta podria representar una de les limitacions del treball: els docents no han pogut comentar i contrastar els resultats del qüestionari dels estudiants i, per tant, les respostes proporcionades han estat, en alguns casos, generalitzades o tòpiques.

En concret, els resultats del qüestionari mostren un alt gust per la lectura dels estudiants de $1 r$ de batxillerat, el qual coincideix amb l'elevat percentatge d'òptima interpretació de la ironia, així com un percentatge inferior d'alumnes de $3 \mathrm{r}$ d'ESO que els agrada llegir respecte als altres grups, la qual cosa podria explicar el tímid 13\% d'encerts pel que fa a la percepció de la ironia. Ara bé, els alts índexs de gust lector mostrats per 1r d’ESO no es tradueixen en una reeixida interpretació de la ironia. Els resultats en la capacitat interpretativa dels estudiants tampoc es veuen reflectits en les xifres sobre el grau d'importància que té pels alumnes la lectura en el seu dia a dia (taula 5) o l'estona dedicada a la lectura setmanalment (taula 7), ans al contrari. Pel que fa a l'autoconcepció que tenen els estudiants de la facilitat envers la comprensió lectora, es demostra que les xifres són molt més positives que les mostrades en els resultats. Cal tenir en compte que la mitjana de respostes encertades en la comprensió lectora per $1 r$ d'ESO és del 33\%, a 3r d'ESO és del $30 \%$ i a $1 \mathrm{r}$ de batxillerat és del $61 \%$. Per contra, la suma de les respostes que se situen entre un bon nivell i un nivell mitjà de facilitat per a comprendre els textos en el qüestionari d'hàbits lectors és d'un 75\% a 1r d'ESO, d'un 93\% a 3r d'ESO i d'un 87\% a $1 r$ de batxillerat. En general, per tant, es demostra que els alumnes tenen una alta autopercepció, no sempre encertada, sobre el propi nivell d'aprenentatge i capacitat en els processos de comprensió lectora.

Per aquest motiu, malgrat que Manresa afirma que «la lectura lliure i voluntària a l'escola és l'eina més afectiva per augmentar l'habilitat [...] de comprensió dels alumnes» (2011, p. 176), els resultats de l'estudi mostren que, en el cas que ens ocupa, no hi ha una correspondència evident entre els bons hàbits lectors dels estudiants i una capacitat reeixida d'interpretació de la ironia.

Aleshores, què caldria fer per millorar la capacitat interpretativa de l'alumnat? Com hem vist, els professors atribueixen aquesta problemàtica a diversos factors: per la seva banda, el docent 1 apunta cap a la manca d'hàbit lector de l'alumnat «perquè ens deixem un agent molt important, que és la família. La família té un paper cabdal amb el tema de lectura» (docent 1). El docent 2 ho atribueix a la necessitat d'augmentar l'estona de lectura a través d'un pla lector i a esperar amb paciència els resultats a llarg termini: «hi ha centres [...] que han tingut un pla lector i al cap de dos anys: "fora, que no funciona". [...] Amb dos anys no ho puc valorar [si funciona], és molt poc temps. [...] L'educació és una llavor. [...] Has de tenir paciència i confiança amb el que fas. Per tant, un pla lector» (docent 2). Ara bé, tal com s'ha demostrat, els resultats del qüestionari d'hàbits lectors no ratifiquen les tesis dels docents 1 i 2 -és a dir, que l'augment de l'hàbit lector milloraria la capacitat interpretativa de l'alumnat-i, per tant, no deixen de ser visions estereotipades i que caldria erradicar. Per últim, el docent 3 es mostra escèptic pel que fa a la possibilitat de canviar l'hàbit lector de l'alumnat a curt termini i considera que caldria incorporar més assignatures humanístiques al currículum educatiu i, en general, fomentar el bagatge de coneixement de l'entorn de l'estudiant (docent 3). Per tant, es pot comprovar que els docents apunten cap a solucions que apel·len a la institució i a les característiques de cada estudiant, però no es proposen millores que impliquin directament la pròpia tasca docent. 


\section{Conclusions i orientacions per treballar la ironia a l'aula}

En el present estudi s'ha analitzat la capacitat de comprensió lectora i d'interpretació de la ironia de l'alumnat de tres cursos diferents del mateix centre educatiu, $1 r$ d'ESO, $3 r$ d'ESO i 1r de batxillerat, a partir de la lectura d'un relat irònic breu de Quim Monzó i la resposta d'una sèrie de preguntes. S'ha pogut determinar que, pel que fa als tres processos de comprensió lectora, els estudiants dominen reeixidament la comprensió literal, presenten algunes mancances pel que fa a la capacitat interpretativa o inferencial de la informació i, per últim, tenen dificultats per dur a terme l'última part del procés: la reflexió.

Pel que fa al primer objectiu del treball, a partir dels resultats de les preguntes de la comprensió lectora, del qüestionari d'hàbits lectors i de les entrevistes a docents s'ha observat que, mentre els estudiants de $1 r$ de batxillerat demostren cert domini del recurs lingüístic, la percepció i interpretació de la ironia literària representen un punt feble en les competències relacionades amb les dimensions de comprensió lectora dels estudiants de $1 \mathrm{r}$ i $3 r$ d'ESO.

S'ha fet palesa una gran diferència entre la capacitat interpretativa de la ironia de l'alumnat de secundària en comparació amb l'alumnat de batxillerat. D'aquesta manera, mentre que els resultats no mostren cap evolució notable entre els nivells de $1 \mathrm{r}$ i $3 \mathrm{r}$ d'ESO, s'ha demostrat que la percepció i interpretació de la ironia està sotmesa a un progrés positiu i creixent, paral-lel al creixement biològic dels estudiants, entre l'etapa d'educació secundària obligatòria i batxillerat.

A partir del contrast entre els resultats, s'ha determinat que les diferents dades que formen part de l'estudi no permeten relacionar proporcionalment els hàbits lectors dels estudiants amb la seva capacitat d'interpretació de la ironia i que els estudiants tenen, en general, una alta autopercepció, no sempre encertada, de la pròpia capacitat de comprensió lectora. Per altra banda, s'ha mostrat que la percepció que tenen els professors entrevistats envers la capacitat lectora i interpretativa dels alumnes coincideix en part amb els resultats observats. Malgrat això, es mostra poca autocrítica envers la tasca docent com a factor responsable de l'òptima capacitat de comprensió lectora dels estudiants. Per tant, l'estudi realitzat en aquest treball ha servit per demostrar i validar la hipòtesi inicial, afirmació que ha motivat la recerca realitzada: als alumnes de secundària els costa percebre i interpretar la ironia textual.

Altrament, i malgrat el seu ús estès a la societat, el currículum educatiu no inclou de manera explícita la ironia en la documentació prescriptiva. Per consegüent, a través de l'observació duta a terme a partir de l'estudi i de les conclusions, aquest treball es planteja un segon objectiu: proposar algunes orientacions $i$ actuacions acadèmiques útils i a tenir en compte per a tot docent a I'hora de treballar la ironia literària a l'aula en forma de decàleg:

\section{El format}

Els resultats de l'estudi han demostrat que l'ús del relat breu o del conte permet treballar especialment la capacitat interpretativa de la ironia gràcies a la seva brevetat, la qual evita que l'atenció del lector es desviï, prioritza l'acció en lloc dels personatges, facilita la consciència del final del relat al lector, exigeix una participació més activa, permet un vincle interpretatiu amb el títol i, en general, facilita la detecció de la ironia a l'estudiant (Barreras, 2014, p. 56). 


\section{El temps}

Formar els estudiants amb una bona competència interpretativa de la ironia no hauria de ser un objectiu a curt termini. El domini d'aquest recurs lingüístic passa per l'observació, la descoberta, la reflexió i la maduració de les capacitats lingüístiques i culturals de l'estudiant i per la necessitat de temps per processar l'informació (Barreras, 2001, p. 248) i, per tant, és necessari un procés continu d'aprenentatge durant l'educació secundària per tal que, al final de l'etapa, l'estudiant posseeixi les eines per comprendre i interpretar la ironia.

\section{El nivell de l'aprenent}

Dominar la ironia és una tasca complexa i, per tant, cal introduir-la als nostres estudiants d'acord amb l'etapa educativa en la qual se situen en cada moment. Per aquest motiu, fora bona l'observació d'exemples d'ironia més simples durant les primeres etapes de secundària i anar augmentant el nivell a mesura que l'estudiant s'hi va familiaritzant, consolida els aprenentatges i hi implica processos cognitius més profunds (Sacristán, 2006, p. 131).

\section{L'acompanyament}

L'acompanyament del professor pel que fa a la identificació i interpretació de les expressions iròniques resulta un suport essencial i imprescindible per a l'alumne. Ara bé, l'ajuda del professor ha de ser ajustada i contingent, de manera que ha de donar peu a un primer aproximament, ha de fomentar l'autonomia interpretativa de l'estudiant i ha de regular els aprenentatges de l'educand per tal que pugui prendre les seves pròpies decisions (Sanmartí, 2010, p. 3).

\section{El treball individual}

Malgrat que un treball col-lectiu a l'aula pot orientar l'estudiant en certs moments del procés d'aprenentatge, la ironia requereix una part imprescindible de treball individual que fomenti l'observació, la participació activa en la interpretació (Barreras, 2014, p. 58) i la reflexió personal, així com la creació de vincles amb els coneixements previs de cada estudiant (Sacristán, 2006, p. 141-142).

\section{Els tres processos fonamentals de comprensió lectora}

Un òptim aprenentatge de la ironia ha de passar prèviament per un treball exhaustiu dels tres processos vinculats en la comprensió lectora: comprensió literal, interpretativa i reflexiva (Decret 187/2015, p. 23). Per tant, cal dissenyar activitats que suposin un repte per als aprenents, que facin posar en pràctica les diferents capacitats a l'alumnat i que impliquin processos cognitius i sabers diversos (Sanmartí, 2010, p. 20).

\section{El bagatge lingüístic i cultural}

L'enriquiment personal de l'alumne i la construcció d'un bagatge cultural ric sempre és un punt a favor de la construcció de les capacitats interpretatives de la ironia i, per tant, cal fomentar en la mesura del possible el contacte amb altres formes de coneixement, més enllà de la llengua i la literatura (Villarrubia, 2010, p. 32).

\section{L'avaluació formativa}

Emprar una avaluació formativa -centrada en l'avaluació per a l'aprenentatge i no pas l'avaluació de l'aprenentatge- ens ajudarà com a docents a regular els coneixements de l'alumne, a fomentar la presa de decisions, la reflexió i l'autoconeixement sobre el propi 
aprenentatge (Sanmartí, 2010, p. 2-5), per la qual cosa reforçarà les capacitats interpretatives i reflexives necessàries per a interceptar i interpretar amb èxit la ironia textual.

\section{La diversitat de suports}

Observar com es presenta la ironia en diversos formats i suports -no només pel que fa a les diferents formes textuals, sinó també en la llengua oral o audiovisual- pot ajudar els estudiants a observar i apreciar les diferents aplicacions, usos, i finalitats que ofereix del recurs comunicatiu (Villarrubia, 2010, p. 35).

\section{La producció irònica}

Vincular la pràctica i l'experiència activa dels estudiants a l'aula en el dia a dia a través d'activitats de producció irònica contextualitzades, productives i complexes (Sanmartí, 2010, p. 22), que obliguin a mobilitzar en els estudiants diferents sabers, pot resultar un recurs molt útil per a consolidar els aprenentatges sobre la ironia.

\section{Referències}

Balaguer, E. (1997) «Quim Monzó i la societat postmoderna. 'El perquè de tot plegat': un comentari de text». Caplletra, 22, p. 81-89.

Ballart, P. (1992) «La ironia com a figuració literària». Els Marges, 47, p. 7-29.

Barreras, A. (2001) «El estudio de la ironía en el texto literario». Cuadernos de Investigación Filológica, 27-28, p. 243-266.

Barreras, A. (2014) El estudio literario de la narración breve y su utilización en el contexto docente. Servicio de Publicaciones, Universidad de la Rioja.

Caro, M. (2017) «De la mariposa a la tormenta: análisis de los comentarios de los lectores en la red a textos argumentativos irónicos». ELUA, 31, p. 97-116.

Caro, M., Camargo, Z. i Uribe, G. (2018) «La ironía revisitada en sus dimensiones pragmáticas, comprensivas, discursivas y didácticas». Lenguaje, 46, p. 95-126.

Decret 187/2015, de 25 d'agost, d'ordenació dels ensenyaments de l'educació secundària obligatòria.

Direcció General d'Educació Secundària Obligatòria i Batxillerat (2015) Competències bàsiques de l'àmbit lingüístic. Departament d'Ensenyament, Generalitat de Catalunya.

Gregori, C. (2010) «Estratègies discursives iròniques en la narrativa catalana actual: I'autoconsciència textual». Revista de Filologia Romànica, 27, p. 59-726.

Gregori, C. (2011) «El títol com a clàusula del contracte metaficcional irònic en la narrativa contemporània.» Carbó, F., Gregori, C., Lluch, G., Rosselló, R. X., Simbor, V. La literatura davant el mirall. Ironia i metaliteratura en l'època contemporània. Barcelona, Publicacions de l'Abadia de Montserrat, p. 47-84.

Larregola, J. (2019, desembre 9) «La fi de la ironia». Eix Diari: diari independent del Penedès. https://www.eixdiari.cat/opinio/doc/86225/la-fi-de-la-ironia.html Consulta 6 de maig de 2020

Llei 12/2009, del 10 de juliol, d'educació. Departament d'Ensenyament, Generalitat de Catalunya (2009).

Lunati, M. (2001) «Quim Monzó i la re-escriptura irònica de la fantasia». Catalan Review, 1, p. 23-51.

Manresa, M. (2011) Els hàbits lectors dels adolescents: efectes de les actuacions escolars en les practiques de lectura (Tesi doctoral). Universitat de Barcelona, Catalunya. 
Maza, M. (2014) «El gènere i l'humor en les interaccions didàctiques d'alumnes de secundària». Feminismo/s, 24, p. 95-114.

Monzó, Quim (1994) «¿Por qué las agujas de los relojes giran en el sentido de las agujas de los relojes?», El porqué de las cosas. Traducció de Marcelo Cohen. Barcelona, Editorial Anagrama.

Monzó, Quim (1999) «¿Perquè les busques dels rellotges giren en el sentit de les busques dels rellotges?», El perquè de tot plegat. Barcelona, Quaderns Crema, p. 55-57.

Ortega, F. J. i Vargas, B. V. (2016) «Aproximación sociopragmática las estrategias conversacionales de los adolescentes». Cuadernos de Lingüística Hispánica, 29, p. 83103.

Pàmies, S. (2018, febrer 9) «Comprensió lectora». La Vanguardia, cultura. https://www.lavanguardia.com/cultura/20180209/44632595727/comprensiolectora.html Consulta 6 de maig de 2020

Roca, S. (2009) «La ironía del professor». Barrientos, A., Martín, J.C., Reyes, V. i Fernández, M.I. El professor de español LE-L2: actas del XIX congreso internacional de la asociación para la enseñanza del español como lengua extranjera, p. 753-764.

Royo, A. (2017) La sociedad gaseosa. Barcelona, Plataforma Editorial.

Sacristán, F. (2006) «Comprensió de la lectura en alumnes d'ensenyament secundari». Anuari de psicologia, Societat Valenciana de Psicologia, 11, p. 131-144.

Sanmartí, N. (2010) Avaluar per aprendre. L'avaluació per millorar els aprenentatges de l'alumnat en el marc del currículum per competències. Departament d'Educació, Generalitat de Catalunya.

Sanuy, M. (2007) «Treballar Quim Monzó a través del cinema». Articles: revista de didàctica de la llengua i de la literatura, 43, p. 84-94.

Traver, L. (2019) El perquè de tot plegat. Anàlisi comparativa de l'adaptació de Ventura Pons del recull de contes de Quim Monzó. La ironia monzoniana a la pantalla. Treball de fi de grau. Universitat Oberta de Catalunya, Catalunya.

Villarrubia, M. (2010) «La ironía y el humor a través de la literatura. Una dimensión de la pragmática cognitiva en la enseñanza del ELE». Revista de Didáctica Español Lengua Extranjera, 10, p. 1-51.

Zamorano, M. J. (2015) La comprensión de sentidos no literales en niños y adolescentes: un estudio comparativo con oyentes, sordos con implante coclear y sordos no implantados (Tesi doctoral). Universidad de Málaga, Andalusia. 


\section{La interpretación de la ironia literaria en estudiantes de secundaria}

Resumen: El presente trabajo propone un estudio cualitativo a través de una actividad de comprensión lectora y de un cuestionario de hábitos lectores a estudiantes de diferentes cursos $-1^{\circ}$ de ESO, $3^{\circ}$ de ESO y $1^{\circ}$ de bachillerato- del mismo centro educativo y de tres entrevistas a docentes para observar cómo perciben la ironía de un texto literario los estudiantes. Los resultados demuestran que la capacidad de interpretación de la ironía resulta un punto débil en las competencias, relacionadas con las dimensiones literarias y de comprensión lectora, de los cursos de $1^{\circ}$ y $3^{\circ}$ de ESO, y mostraron, en cambio, un cierto dominio de estas competencias en $1^{\circ}$ de bachillerato. Como consecuencia, el trabajo propone algunas actuaciones y orientaciones didácticas dirigidas a los docentes para trabajar la ironía en el aula.

Palabras clave: Ironía, interpretación, reflexión, secundaria, aprendizaje, literatura, comprensión lectora.

\section{L'interprétation de l'ironie littéraire chez les étudiants du secondaire}

Résumé: Ce travail propose une étude qualitative à travers une activité de compréhension écrite et un questionnaire d'habitudes de lecture auprès d'étudiants de différents niveaux d'études - classes de $5^{\mathrm{e}}$ et de $3^{\mathrm{e}}$ au collège et de $1^{\text {ère }}$ au lycée - du même établissement scolaire, et à travers trois entretiens menés auprès d'enseignants afin d'observer comment les étudiants perçoivent l'ironie d'un texte littéraire. Les résultats démontrent que la capacité d'interprétation de l'ironie s'avère être un point faible dans les compétences, liées aux dimensions littéraires et de compréhension écrite, des niveaux de classes de $5^{\mathrm{e}}$ et de $3^{\mathrm{e}}$; et montrent, en revanche, une certaine maîtrise de ces compétences dans les classes du niveau de $1^{\text {ère }}$. En conséquence, ce travail propose certaines actions et orientations didactiques adressées aux enseignants pour travailler l'ironie en classe.

Mots-clés: Ironie, interprétation, réflexion, secondaire, apprentissage, littérature, compréhension écrite.

\section{The interpretation of literary irony in high school students}

Abstract: The following project proposes a qualitative study through a reading comprehension activity and a reading habits survey administered to students from different grades $\left(1^{\text {st }}\right.$ and $3^{\text {rd }}$ of secondary school and $1 \mathrm{rt}$ of pre-university studies) at the same school and through three teacher interviews to observe how certain students perceive irony in a literary text. The results prove that the ability to interpret irony represents a weakness in $1^{\text {st }}$ and $3^{\text {rd }}$ grade secondary students' competencies, which are related to literary and reading comprehension dimensions, but, in contrast, show a greater proficiency among pre-university students. The project suggests some teaching activities and guidance for teachers to study irony in their lessons.

Keywords: Irony, interpretation, reflection, secondary school, learning, literature, reading comprehension. 